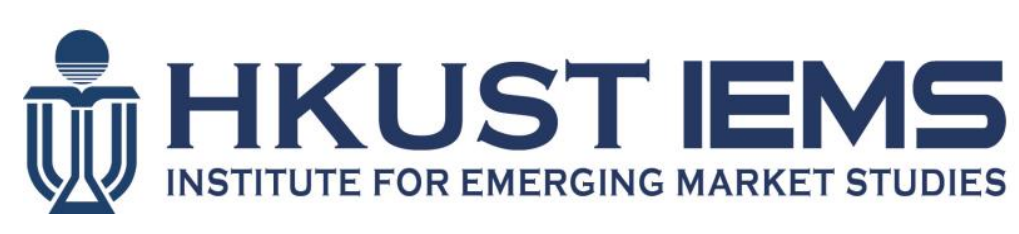

\title{
Board Reforms and Firm Value: Worldwide Evidence
}

\author{
Larry FAUVER, Mingyi HUNG, Xi LI, Alvaro TABOADA
}

HKUST IEMS Working Paper No. 2015-20

March 2015

\begin{abstract}
HKUST IEMS working papers are distributed for discussion and comment purposes. The views expressed in these papers are those of the authors and do not necessarily represent the views of HKUST IEMS.
\end{abstract}

More HKUST IEMS working papers are available at: http://iems.ust.hk/WP 


\title{
Board Reforms and Firm Value: Worldwide Evidence
}

Larry FAUVER, Mingyi HUNG, Xi LI, Alvaro TABOADA

HKUST IEMS Working Paper No. 2015-20

March 2015

\begin{abstract}
We examine the impact of corporate board reforms on firm value in 41 countries. Using a difference-in-differences design, we find that firm value increases after enactment of the reforms. The valuation increase is associated with both the intensity and major components of the reform, including board independence, audit committee, and the separation of the roles of chief executive officer and chairman. We also find that the effect of these reforms primarily exists in countries with weak legal institutions. In addition, the effect of reforms is concentrated among comply-or-explain reforms, and the role of country-level institutions is less important for these reforms than for regulation reforms. Taken together, our findings suggest exogenously introduced governance changes benefit shareholders, mainly in countries with weak institutional quality and for reforms with a comply-or-explain approach.
\end{abstract}

\section{Author's contact information}

Larry Fauver

University of Tennessee

Mingyi Hung

The Hong Kong University of Science and Technology

Xi Li

Hong Kong University of Science and Technology

Clear Water Bay, Hong Kong

T: 852-2358-7560

E : acli@ust.hk

Alvaro Taboada

University of Tennessee 


\title{
Board Reforms and Firm Value: Worldwide Evidence
}

\author{
Larry Fauver, ${ }^{\dagger}$ Mingyi Hung, ${ }^{*}$ Xi Li, $*$ Alvaro Taboada ${ }^{\dagger}$ \\ ${ }^{\dagger}$ University of Tennessee \\ * Hong Kong University of Science and Technology
}

December 2014

\begin{abstract}
We examine the impact of corporate board reforms on firm value in 41 countries. Using a difference-in-differences design, we find that firm value increases after enactment of the reforms. The valuation increase is associated with both the intensity and major components of the reform, including board independence, audit committee, and the separation of the roles of chief executive officer and chairman. We also find that the effect of these reforms primarily exists in countries with weak legal institutions. In addition, the effect of reforms is concentrated among comply-orexplain reforms, and the role of country-level institutions is less important for these reforms than for regulation reforms. Taken together, our findings suggest exogenously introduced governance changes benefit shareholders, mainly in countries with weak institutional quality and for reforms with a comply-or-explain approach.
\end{abstract}

JEL classification: G15; G34; K22

Keywords: Cross-country study; firm value; governance reforms

Acknowledgments: We would like to thank, Qianqian Huang, and seminar participants at the Hong Kong University of Science and Technology, the University of Kentucky, and the University of Tennessee for helpful comments. 


\section{Board Reforms and Firm Value: Worldwide Evidence}

\section{INTRODUCTION}

The last two decades witnessed a worldwide explosion of corporate board reforms that aimed to increase firm value by imposing or recommending specific guidelines including board independence, audit committee composition, and the separation of CEOs and chairmen. In addition to considerable attention by investors and regulators, these reforms are the focus of a growing body of research because they provide quasi-natural experimental research setting that alleviates the endogeneity concern of examining the relationship between board composition and performance. However, the existing research typically focuses on a single country and yields mixed results. ${ }^{1}$ Thus, two important but unanswered questions arise: Do board reforms, on average, increase firm value? How does their impact vary with the existing country and firm institutional quality? In this paper, we address these questions by assessing the impact of major corporate board reforms on firm value around the world.

We focus on governance reforms related to board practices because boards are the fundamental governance mechanism of corporations and because these reforms are the major approach to address corporate governance issues. ${ }^{2}$ Board reforms are ubiquitous around the world, covering essentially every country in the MSCI developed and emerging market lists. However, the effectiveness of the reforms in achieving the stated goal of shareholder protection and firm value maximization is highly debated.

\footnotetext{
${ }^{1}$ While some studies find that the reform is associated with increases in firm values in countries such as India, South Korea and the U.K. (Black and Khanna 2007, Black and Kim, 2012, and Dahya and McConnell 2007, respectively), other studies find the reform has negative effect on firm value in the U.S. (Zhang 2007; Li 2014).

${ }^{2}$ Having a corporate board is one of the legal requirements for incorporation and the role of boards to mitigate agency conflicts and protect shareholder interest has long been recognized in the literature. Hermalin and Weisbach (2003) and Denis and McConnell (2003) review the studies on U.S. boards and non-U.S. boards, respectively.
} 
A common feature of the reforms, including the Cadbury recommendations in the U.K. and the Sarbanes-Oxley Act (SOX) in the U.S., is the emphasis on outside representation on the board. Proponents of the reforms suggest that more outside representation should be encouraged or mandated because of the agency problems that arise from the incentive and ability of corporate insiders (managers and controlling shareholders) to extract private benefits. By improving board oversight, insiders may be more likely to invest in projects that benefit all shareholders and improve financial reporting quality to safeguard firm assets and communicate the future prospects, thereby increasing outsiders' willingness to finance the firm and also reducing cost of capital (Jensen and Meckling 1976).

However, critics of the reforms argue that the existing board practices are an outcome of market solutions and likely reflect the best possible contracting arrangements resulting from a firm's operational complexity and information environments among private parties. Thus, board reforms that push firms away from this arrangement may be unnecessary and potentially harmful. For example, firms optimally appoint insiders to the boards, as they possess greater firm-specific knowledge and can make better strategic and investment decisions (Harris and Raviv 2006). In summary, the average effect of board reforms on firm value is an empirical question.

While we do not have a directional prediction on the average effect of board reforms on firm value worldwide, we expect that board reforms are more beneficial to shareholders in countries with poorer ex ante institutional quality. We reason that shareholder expropriation is more prevalent in countries with weaker investor protection (La Porta et al. 1997, 2002). Thus, firms in countries with weak institutional quality may stand to gain more from board reforms. In addition, the disclosure quality is poorer in countries with weaker investor protection, resulting 
in greater asymmetric information between the parties at the time of contracting in these environments. Since information asymmetry leads to distortions that are undesirable from an ex ante perspective, reforms that correct these distortion can be valuable (Aghion and Hermalin 1990). Based on these arguments, we hypothesize that governance reforms lead to a greater increase in firm value in countries with poorer ex ante institutional quality. ${ }^{3}$

Our empirical analysis examines a set of major governance reforms in 41 countries between 1990 and 2012 using a sample of 196,016 firm-years (32,656 firms) meeting our sample restrictions. We begin our sample period in 1990 because international databases have limited coverage of non-U.S. firms prior to 1990. In addition, the push for improvements in corporate governance is a relatively recent phenomenon triggered by the publication of the U.K.'s 1992 Cadbury Report, titled Financial Aspects of Corporate Governance and issued by the Committee on the Financial Aspects of Corporate Governance, which was chaired by Adrian Cadbury (Aguilera and Cuervo-Cazurra 2004; Dahya and McConnell 2007; and Cicon et al. 2012). Using a difference-in-differences (DID) design, we find that on average firm value increases following enactment of the reforms.

We use several approaches to mitigate potential concerns of our DID estimation. First, to address the concern of changing economic conditions, we examine the effect of reforms during the years surrounding the reforms. Our results continue to hold. We also find that the increase in firm value materializes on or after the board reforms become effective in the country, and there is no evidence suggesting firm value increases prior to the reform. Second, the DID design

\footnotetext{
${ }^{3}$ Prior studies on financial disclosure reforms, such as mandatory International Financial Reporting Standards adoption, suggest that positive economic consequences of increased disclosure depend on implementation credibility and, therefore, mainly exist in countries with strong institutional quality (DeFond et al., 2011). Unlike financial reporting regulation, which is subject to great managerial judgment and discretions of alternative accounting choices and estimates, compliance with board reforms, such as board independence and CEO and chairman duality, is relatively straightforward and verifiable by outsiders and regulators. Thus, the implementation credibility is less of a concern in our setting.
} 
assumes that in the absence of treatment, the average change in the response variable would have been the same for the treated and untreated groups. To assess the validity of this assumption, we conduct two placebo tests using pseudo reform years during both the pre-reform periods and post-reform periods. We find no evidence suggesting changes in firm value subsequent to the pseudo reform years. Finally, we use alternative DID specification by restricting our sample period to begin in 2000 and using propensity-score-matched (PSM) firms in the U.K., the major country passing the board reform before 2000, as the benchmark. We again find our results remain qualitatively similar.

We also explore some interesting heterogeneity of the reforms. We examine the effect of three major components of board reforms: (1) board independence, (2) establishment of an audit committee or the appointment of external auditors, and (3) the separation of the CEO and chairman positions. Most reforms involve provisions related to board independence and auditing, while only a few reforms require the separation of the roles of CEO and chairman. On average, stronger reforms (i.e., reforms involving more components) and reforms involving each of the three components have a positive effect on firm value.

Our analysis examining the effect of legal institutions finds that the increases in firm value subsequent to board reforms exist mainly in countries with weak legal institutions. These findings are consistent with our predictions and suggest that exogenous governance changes benefit shareholders in countries with poor institutional environments. We further corroborate this inference by examining the impact of the reforms conditional on firm-level governance characteristics, as captured by the governance index from Aggarwal et al. (2011), and information environments, as captured by analyst coverage and forecast dispersion. We find that 
the valuation increases associated with board reforms mainly exist among firms with weaker firm-level governance quality and poorer firm-level information environments.

Another interesting aspect of board reforms is the heterogeneity in countries' approach in implementing the reforms. Some enact regulations and others introduce comply-or-explain codes (also called codes of best practices) in which firms can choose to explain why they do not comply. Supporters of regulations argue that voluntary codes do not have teeth. Supporters of comply-or-explain codes argue that one-size-fits-all regulations give firms little flexibility and the related costs to firms may exceed the benefits. Further, they point out that codes carry the threat that regulations would follow if firms do not comply with codes without a clear explanation. ${ }^{4}$ We find that on average firm value increases following comply-or-explain reforms, but not regulation reforms. While the positive effect of regulation reforms is more pronounced in countries with weaker legal institutions, little evidence exists that the positive effect of complyor-explain reform varies with legal institutions. Flexibility inherent in comply-or-explain reforms may yield more benefits, especially for firms in countries with strong institutional quality, while the one-size-fits-all regulation reforms in such countries may be less beneficial.

To further corroborate our inferences, we also investigate the impact of board reforms on several channels that may lead to improved firm value, including firm profitability, reporting quality, and investment-cash flow sensitivities (Anderson et al. 2004; McLean et al. 2012). We find that firms experience an improvement in profitability and reporting quality and a decline in investment-cash flow sensitivity after enactment of the reforms. These results suggest that board reforms improve operating efficiency, reporting quality and outside financing opportunities, thereby supporting our main findings that these reforms increase firm value. In addition, our

\footnotetext{
${ }^{4}$ For example, the Cadbury Report (Section 1.1) explicitly acknowledges that legislation would very likely follow if companies did not comply with the guidelines.
} 
conclusions remain unchanged after excluding U.S. firms from our sample and using alternative measures of Tobin's Q (i.e., our valuation measure).

Our study contributes to the literature in several ways. First, our paper assesses the impact of a broad set of major board reforms around the world and identifies factors explaining their effectiveness. The reforms that we focus on are quasi-natural experiments exogenous to firms within a country, thereby mitigating the endogeneity concerns in earlier governance research. Although a growing body of literature also examines exogenous changes in governance, it generally focuses on one reform in one country and primarily in the U.S. This approach provides mixed evidence across countries and limits the generalization of the findings. By taking advantage of board reforms around the world, our study adds to this literature by reconciling the mixed findings in prior single-country studies and documenting factors affecting the heterogeneity in the firm value effect of board reforms. Our study highlights the importance of considering existing governance and information environments when formulating guidelines to improve governance practices.

Second, our paper is relevant to the literature showing a significant positive relation between firm value and quality of a country's legal institutions (La Porta et al., 2002). A common view of this literature is that changing country-level institutions is a slow process and that certain customs, such as a law and order tradition and judicial efficiency, are stable over time (North, 1990). Our study complements this literature by documenting that reforms pertaining to board structures help mitigate the weaknesses of the existing legal institutions and improve firm valuation.

Finally, our study adds to the ongoing debate of governance regulations worldwide. With increasing globalization, considerable interest has arisen in reforming corporate boards to 
improve investors' confidence and attract foreign investors. ${ }^{5}$ Given the focus of the existing literature on a single reform, little is known about what aspects of governance changes and what types of reforms are more beneficial to shareholders. Our study provides insights into this debate by documenting that comply-or-explain reforms are more effective at increasing firm value than one-size-fits-all regulations. In addition, provisions related to board independence and auditing are more effective than those related to CEO-chairman duality.

The rest of the paper is organized as follows. Section II develops our hypotheses. Section III describes the sample, data, and research design. Section IV discusses our results on board reforms and firm value. Section V presents the results of additional analyses and sensitivity tests. Section VI concludes.

\section{HYPOTHESES DEVELOPMENT}

Since the U.K.'s Cadbury Report was issued in 1992, scores of countries have launched corporate board reforms (Dahya and McConnell 2007). These reforms affect all major developed and emerging economies and, as the Cadbury Report, their focus is on the role and composition of corporate boards, such as the appointment of independent directors, audit committee and auditor, and CEO and chairman positions. ${ }^{6}$ The ultimate reason why many countries have placed so much emphasis on enhancing corporate governance mechanisms is reflected in the following excerpt from the 2009 Latin American Corporate Governance Roundtable:

"The improvement of corporate governance practices is widely seen as one important element in strengthening the foundation for individual countries' long-term economic performance and in contributing to a strengthened international financial system."

\footnotetext{
${ }^{5}$ See “Corporate-Governance Code Is Urged in Japan,” Wall Street Journal, May 27, 2014.

${ }^{6}$ Dahya and McConnell (2007) refer to this phenomenon as "outside director euphoria."
} 
In addition to the economic and regulatory significance, the worldwide board reforms also provide a unique setting to test the effect of board structure on firm performance. Since the shock is exogenous to individual firms, our results are not subject to endogeneity and selfselection concerns that plagued prior governance literature (Hermalin and Weisbach 2003; and Wintoki et al. 2012). That is, because board characteristics and firm performance are endogenously determined, determining whether governance drives performance (or vice versa) or whether governance and performance are both driven by unobservable factors is difficult to ascertain (Hermalin and Weisbach 2003; and Wintoki et al. 2012).

The effect of the reforms on shareholder value, however, is highly debated. This is because there are different interpretations of the board practices prior to the reforms. One interpretation is that boards are captured by top executives and controlling shareholders to facilitate shareholder expropriation and minimize oversight. Under this view, board reforms should be encouraged or mandated. That is, improved board oversight, such as greater independence, help protect outside investors (both shareholders and creditors) by reducing the expropriation of controlling shareholders or the stealing, shirking, and overconsumption of perks by company managers (Jensen and Meckling 1976). In addition, as governance improves, insiders (both managers and controlling shareholders) may be more likely to invest in projects that benefit all shareholders instead of just themselves, which makes investors more willing to pay for firms' financial assets such as equity and debt; this in turn, relaxes financial constraints and allows firms to undertake more profitable investment opportunities. Consistent with this view, the Cadbury Report states:

"The country's economy depends on the drive and efficiency of its companies. Thus the effectiveness with which their boards discharge their responsibilities determines Britain's competitive position. (Cadbury Report, 1 December 1992)." 
However, another interpretation of existing board structures is that existing governance practices, which are around for a long time, are outcome of market solutions and likely reflect the best possible contracting arrangements among private parties. Under this view, board reforms are unnecessary and potentially harmful. For example, while independent directors are supposed to act as a counterweight to insiders, these directors lack firm-specific expertise and the incentive to acquire expertise, especially when they try to free ride the effort of other independent directors. They also may be more conservative than insiders because their reputation and compensation depend less on firm's earnings growth and profitability, and they care more about avoiding lawsuits and protecting reputation. As a result of the constraints from independent directors, insiders may also become overly risk averse in their investment decisions and lose much of the discretion and flexibility critical to robust growth. In addition, insiders may not want to reveal full or complete information to independent directors, which may lead to suboptimal decisions made by these directors. Consequently, the exogenously imposed changes in board structures, especially those of the one-size-fit-all variety, reduce firm values. Consistent with this view, prior research finds evidence suggesting that costs of SOX compliance significantly exceed its benefits and reduce the net benefits of both U.S. firms and foreign firms cross-listed in the U.S. (Zhang 2007; Li 2014 ).

In summary, based on the above arguments, we are unable to provide a directional prediction of their average effect on firm value in Hypothesis 1, which is:

Hypothesis 1: Firm value may either increase or decrease following enactment of board reforms.

While it is difficult to predict the average effect of governance reforms, we expect that an important condition for the reforms to potentially increase shareholders' welfare is the ex-ante 
institutional environment. The law and finance literature, starting with La Porta et al. (1997, 1998), shows that legal environment is a significant factor in explaining capital market development, corporate governance outcome, and financial reporting quality (DeFond and Hung 2004; McLean et al. 2012; Srinivasan et al. 2014). One implication from this literature is that shareholder expropriation, usually through the exploitation of weaknesses in governance mechanisms, is likely to be more prevalent in countries with poor institutional quality (or weak legal institutions). In addition, the relatively poor disclosure quality and great information asymmetry in these environments likely lead to distortions in contracts that are undesirable from an ex ante perspective (Aghion and Hermalin 1990).

The above reasoning suggests that firms in countries with weak institutional quality may stand to gain more from board reforms, because the marginal benefits are greater and the risk of overregulation is lower. In contrast, in countries with strong institutional quality, in which property rights are well protected and contracts are adequately enforced, existing governance practices likely reflect value-maximizing contracts between managers and shareholders. Thus, additional regulation runs the risk of becoming overregulation, with the costs of inflexibility and compliance outweighing the reduced expropriation risks. Consequently, we predict that board reforms have a more positive impact on firm value in countries where the existing institutional quality is weaker.

Hypothesis 2: Firm values increase more in countries with weaker ex ante institutional quality following enactment of board reforms.

Finally, our setting focuses on board reforms, not mandatory financial disclosure. Thus, our predictions differ from those in studies based on mandatory financial disclosure, which argue and find that the positive economic consequences of increased disclosure mainly exist in 
countries with strong institutional quality (DeFond et al. 2011). We mainly focus on reforms established through publication of codified corporate governance norms or amendments to laws pertaining to the role and composition of the corporate board. Unlike mandatory International Financial Reporting Standards (IFRS) adoption, which is principles-based and subject to great managerial discretion, compliance with board reforms in our setting is relatively easy to monitor by outsiders and regulators. Thus, we expect the implementation credibility of board reforms to be less of a concern.

\section{SAMPLE, DATA, AND RESEARCH DESIGN}

\section{Worldwide Board reforms}

We collect information on major corporate board reforms pertaining to corporate boards from 1990 through 2012 for all countries with available stock price and financial data in Thomson Financial's DataStream and WorldScope databases. Following the U.K. Cadbury Report, reforms related to board practices have been a key common regulatory approach to address corporate governance issues during the 1990s and beyond. Our primary sources for corporate board reforms are reports from the World Bank, European Corporate Governance Institute (ECGI), local stock exchange regulators, and prior studies (Kim and Lu 2013). ${ }^{7} \mathrm{We}$ verify the information obtained in these reports and websites using various other sources, including websites of the countries' primary regulators. We identify the major reforms cited in the various reports on corporate governance noted above and the year in which they were implemented. For some countries with more than one reform, we use the earliest identified broad

\footnotetext{
${ }^{7}$ In particular, the Reports on the Observance of Standards and Codes (ROSC) published by the World Bank were used extensively in assessing the importance of various reforms enacted in emerging markets and in determining the major corporate board reforms during our sample period.
} 
board reform during our sample period as an alternate reform (first reform) and conduct separate analyses using this reform.

For each reform, we further code whether it addresses the following three components of board structure characteristics: (1) board independence, (2) audit committee and auditor requirements, and (3) CEO and chairman roles. Each components is coded as one if, respectively, a reform explicitly requires independent directors, the establishment of an audit committee or the appointment of external auditors, and the separation of the CEO and chairman positions. We also code whether a reform is a comprehensive reform that includes additional governance characteristics, such as compensation disclosure and approval, insider trading rules, and protection of minority shareholders. In addition, we classify board reforms into two types: comply-or-explain reforms and regulations. The comply-or-explain reforms (codes of best practices) typically involve publication of governance codes where firms can choose to adopt the recommendations or explain why they do not comply. An example of comply-or-explain reforms is the U.K.'s 1998 Combined Code, which merged the recommendations contained in the Cadbury Report and the 1995 Greenbury Report and contains provisions such as that a decision to combine the posts of chairman and chief executive officer in one person should be publicly justified. Regulation reforms typically involve enactment of company laws or securities regulations that require firms to follow the specified governance practices. ${ }^{8}$ For example, the U.S. Sarbanes-Oxley Act mandates that the majority of the board be independent.

\footnotetext{
${ }^{8}$ While Salterio et al. (2013) classify the 2004 reform in Canada as comply-or-explain, Kim and Lu (2013) classify it as regulation. For consistency, we follow Kim and $\mathrm{Lu}$ for countries covered in their study. Our additional analysis (untabulated) finds that our results are not sensitive to the alternative coding of reform types for Canada.
} 
Table 1 shows the years, key components, and types of reforms by country. ${ }^{9}$ Panels A and $\mathrm{B}$ describe the major reforms and the first reforms, respectively. Panel A shows that there is no concentration of reforms in any single year. In addition, most major reforms involve provisions related to board independence and audit committee (31 and 36 reforms, respectively), but only ten reforms require the separation of the roles of CEO and chairman. Panel A also highlights cross-country differences in the approach taken to implement board reforms. That is, major corporate board reforms are fairly evenly divided between comply-or-explain reforms (22 countries) and regulation reforms (19 countries). Appendix A provides a detailed description of the reforms for each country.

\section{Sample and Data}

For all of the countries for which we identify major reform events, we collect stock price data from DataStream and financial data from WorldScope. We begin with the stocks in DataStream country lists (including delisted stocks) and apply various filters recommended in prior studies to include only common stocks in our final sample (Ince and Porter, 2006; and Griffin et al., 2010). ${ }^{10}$ To be part of our final sample, firms must have data on total assets and Tobin's $q$ (market value of equity plus book value of assets minus the book value of equity divided by book value of assets). We exclude firms with negative sales or negative book value of equity and those with total assets less than $\$ 10$ million, to make firms more comparable across countries. In addition, we follow the literature and exclude firms in regulated industries (financials and utilities, with standard industrial classification codes 6000-6999 and 4900-4949).

\footnotetext{
${ }^{9}$ Five countries, Brazil, Colombia, Czech Republic, Hungary, and Switzerland have a value of zero for the three major components. This is because these reforms mainly pertain to definitions of the board responsibilities, the election of boards, or disclosure of board practices. We include these countries for completeness, but our results are not affected by excluding them.

${ }^{10}$ For example, we eliminate unit trusts, warrants, and other non-common equities using the various generic and country-level filters detailed in Tables B1 and B2 of Griffin et al. (2010). This process eliminates non-common equity securities that are not identified as such by the equity type variable in DataStream.
} 
The sample period varies by country due to data availability. A country enters the sample either in 1990 or in the first year when WorldScope has data available on total assets and market value of equity for at least ten firms. After imposing these restrictions, our final sample consists of 196,016 firm-years (32,656 firms) from 41 countries.

To test Hypothesis 2, we use the rule of law index (Rule of Law) from Kaufmann et al. (2009) as our primary measure of a country's legal institutions. We also use two alternative measures: (1) the disclosure requirements index (Disclosure) from La Porta et al. (2006) and (2) the legal origin (Code Law) from La Porta et al. (1998). Lower values of the rule of law and disclosure indexes and a code-law legal origin indicate weaker institutional quality. We obtain other country-level control variables from the World Bank's World Development Indicators. Appendix B provides data definitions.

Table 2 reports the distribution of our sample by country. The sample is geographically diverse, and the distribution of firms per country varies widely. The U.S. has the largest number of firms $(9,714)$, followed by the U.K. $(2,911)$ and Japan $(2,782)$. Hungary $(42)$ and Colombia (44) have the fewest number of firms.

Table 3 presents descriptive statistics and correlations for the firm- and country-level variables used in our primary analyses. To mitigate the influence of outliers, all firm-level variables are winsorized at the top and bottom $1 \%$ of the distribution. Panel A shows that the mean (median) Tobin's $q$ is 1.65 (1.17) among our sample firms. In addition, our sample is made up of relatively large firms, with mean (median) assets of \$255 million (\$236 million). Panel B of Table 3 shows that, in line with the literature, Tobin's $q$ is positively associated with institutional quality (i.e., Rule of Law and Disclosure).

\section{Research Design}


To test our hypothesis of the average effect of board reforms on firm value, we use a DID design by regressing firm value, measured as Tobin's $q$, on an indicator variable that captures the post-reform period (Post). Because our setting involves multiple treatment groups and time periods (Wooldridge 2007), we include a full set of time effects (i.e., year fixed effects) and a full set of group effects (i.e., country fixed effects). The year and country fixed effects identify the within-year and within-country change in firm valuation between treatment and control groups when countries conduct reforms. This approach implicitly takes as the control group all firms from countries without reforms as of a particular time and is commonly used in prior literature (e.g., Bertrand and Mullainathan 2003; Hail et al. 2014).

Our regression model also includes several additional firm-level, country-level, yearlevel, and industry-level control variables used in prior research to explain Tobin's q (Aggarwal et al. 2009; Gompers et al. 2010; Doidge et al. 2004). Specifically, we include the following firm-level control variables: (1) Size, measured as the log of book value of assets; (2) Age, the log of firm age; Leverage, debt divided by total assets; (3) Cash, cash divided by total assets; (4) $P P E$, property, plant, and equipment divided by sales; (5) Foreign Sales, the two-year average foreign sales divided by sales; (6) $R \& D$, the two-year average research and development expenses divided by sales; (7) Capex, capital expenditures divided by total assets; (8) Closely Held, the percentage of a firm's shares that are closely held; and (9) $A D R$, a variable indicating firms cross-listed on U.S. stock exchanges. We include the following country-level variables: $\log G D P$, the log of GDP per capita as a measure of economic development, and $F D I$, foreign direct investment measured as net inflows as a percent of GDP. In addition to including year fixed effects to control for time effects, our model contains a variable to control for time trend in Tobin's $q$ of an industry, Industry $q$, defined as annual median $q$ in firm $i$ 's industry. We also 
include industry fixed effects to control for industry-level factors that may affect Tobin's q. Our regression model for testing the first hypothesis follows:

$$
q_{t}=\alpha+\beta_{1} \text { Post }_{t}+\sum \beta_{m} \text { Controls }+\sum \beta_{n} F E+\varepsilon_{i t},
$$

Our variable of interest is $\beta_{1}$. While we do not have a directional prediction under Hypothesis 1 , a negative (positive) coefficient on $\beta_{1}$ is consistent with an increase (a decrease) in firm value.

We test our second hypothesis by further including an interaction term between the dummy variable indicating post-period (Post) and a dummy variable indicating countries with weak institutions (INST). We capture weak institutional environments as low rule of law, poor disclosure requirement, and a Code Law legal origin. Our regression model for testing the first hypothesis follows:

$$
q_{i c t}=\alpha+\beta_{1} \text { Post }_{c t}+\beta_{2} \text { Post }_{c t} \times I N S T_{c}+\beta_{3} I N S T_{c}+\sum \beta_{m} \text { Controls }+\sum \beta_{n} F E+\varepsilon_{i t},(2)
$$

Our variable of interest is $\beta_{2}$, which captures the changes in firm value in firms with weak legal institutions relative to firms with strong legal institutions. Hypothesis 2 predicts $\beta_{2}$ to be positive. In all regression estimations, we use robust standard errors clustered by country because reforms are a country-level decision.

A key underlying assumption of the DID approach is that we are able to separate the effects of the board reform from other factors potentially affecting firm value. We do not restrict our control group to countries without a reform over our sample period because these countries are small economies with a limited number of firms. In fact, our sample countries represent close to $95 \%$ of the total market capitalization worldwide, while our approach is fairly standard in the literature (Bertrand and Mullainathan 2003; Hail et al. 2014). To assess the validity of our empirical identification strategy, we conduct a series of robustness and falsification tests when discussing our empirical analyses in the next section. 


\section{EMPIRICAL ANALYSIS}

\section{Test of Hypothesis 1}

\section{Average Effects of Board reform on Firm Value}

Table 4 presents the results testing our first hypothesis, the average effect of board reforms on firm value. Columns (1) and (2) report the results for the major reforms, and Columns (3) and (4) report the results for the first reforms. Columns (1) and (3) are the baseline DID models including only our variable of interest and the country, industry, and year fixed effects. Columns (2) and (4) are our full regression models including the full set of controls. We find that the coefficients on Post are significantly positive in all columns, suggesting that Tobin's $q$ increases following the enactment of board reforms. In terms of economic significance, Column (2) shows that Tobin's $q$ on average increases by $3.9 \%$ following the reforms. ${ }^{11}$ Column (4) shows a similar change for the first reforms.

Panel A of Table 4 also shows that the coefficients on the control variables are generally consistent with prior studies. For example, as with Aggarwal et al. (2009), we find that firms with higher cash holdings and greater capital expenditure have higher Tobin's $q$. Also, as with Doidge et al. (2004), we find that cross-listed firms have higher Tobin's q.

To mitigate potential concerns that the findings in Panel A of Table 4 are driven by concurrent institutional or economic changes unrelated to the board reforms, we perform several analyses and present the results in Panel B of Table 4. First, one concern for our DID approach is that the reforms may be passed in response to changing economic conditions. To address this concern, we replace the Post indicator with indicator variables that track the effect of the reforms

$113.9 \%=0.065 / 1.65$, where 0.065 is $\beta_{l}$ in Column (2) of Table 4, Panel A, and 1.65 is mean Tobin's $q$ in Table 3, Panel A. 
before and after they become effective. We include the following four indicator variables: Year 1, Year 0, Year 1, and Year 2+. Year 1 (Year 0, Year-1) equals one for the year of the reform enactment (the year prior to the reform enactment, the two years prior to the reform enactment), and zero otherwise. Year 2+ equals one for the year and subsequent years after the reform becomes effective and zero otherwise. If the reforms are passed in response to changes in economic conditions, one might expect an effect prior to the enactment of the reform. As indicated in Columns (3) and (4) of Panel B, we do not find such a spurious effect. That is, these columns show an insignificant coefficient on the Year -1 and Year 0 indicator variables, suggesting that the increase in firm value materializes on or after the board reform became effective in the firm's country.

Second, the DID design assumes that in the absence of treatment, the average change in the response variable would have been the same for the treated and untreated groups. To assess the validity of this assumption, we conduct two placebo tests. The first placebo test restricts the analyses to the pre-reform periods and sets the pseudo reform enactment year as five years prior to the actual reform enactment year. The second placebo test restricts the analyses to the postreform periods and sets the pseudo reform enactment year as five years after to the actual reform enactment year. The results, presented in Columns (3)-(6) of Table 4, Panel B, show that the coefficients on $P O S T \times Q S U E \times$ Treatment are all insignificant at conventional levels for the analyses of the major and first reforms in both tests. Thus, these findings suggest that, in the absence of treatment, our treatment and benchmark samples exhibit a similar trend in Tobin's q.

Finally, our primary analyses include full sample periods so we have a comparable set of firms and countries in each year. Because our DID design uses non-reform years as the benchmark, this approach also allows us to have a sufficiently large number of benchmark firms 
regardless of the year of the reform. ${ }^{12}$ Nonetheless, we repeat our analyses after restricting the sample period to the ten years surrounding the adoption of the board reforms, $[-5,+5]$ years, and requiring firms to have at least two observations during the pre- and post-periods. Columns (7) and (8) in Table 4, Panel B, present the results of this analysis for the major and first reforms, respectively. We find that our results continue to hold, and the magnitude of the coefficients on Post is about $30 \%$ larger when we restrict our analysis to the ten years surrounding each reform.

\section{Alternative DID Specifications}

This section performs analyses that implement alternative DID specifications by using U.K. firms as the benchmark group. Specifically, we begin our sample period in 2000 and use the PSM approach to identify comparable benchmark firms from the U.K., the largest economy with reforms prior to 2000. Next, we assign the pseudo reform year to the benchmark PSM-U.K. firms based on the reform year of the matched firm. Appendix $\mathrm{C}$ describes the procedure to develop our PSM-U.K. benchmark firms. We then regress Tobin's $q$ on: (1) a dummy variable indicating whether the firm is in a country with board reform (Treatment), (2) a dummy variable indicating whether the period is post-reform (Post), (3) the interaction term between these two indicator variables, and the same set of control variables as in Eq. (1). We perform this analysis using the $[-5,+5]$ year window, rather than the full sample period, because our benchmark firms are all U.K. firms and a shorter window helps mitigate confounding events. Our regression model follows:

$$
q=\alpha+\beta_{1}(\text { Post })+\beta_{2}(\text { Treatment })+\beta_{3}(\text { Post } \times \text { Treatment })+\sum \beta_{m} \text { Controls }+\sum \beta_{n} F E+\varepsilon_{i t},
$$

The coefficient on Post, $\beta_{1}$, reflects the change in Tobin's $q$ for the benchmark group and the coefficient on Treatment, $\beta_{2}$, represents the difference between the benchmark and treatment

\footnotetext{
${ }^{12}$ For example, if we restrict each country to enter our sample only during the event window $[-5,+5]$ years, the benchmark countries in the pre-reform period and post-reform period for a treatment country will differ because the reforms do not happen in the same year.
} 
groups in the pre-period. We do not have directional predictions for these two coefficients because they serve as controls for group-specific and time-specific effects in the DID design (Wooldridge 2002). If board reforms lead to higher firm value, we expect a positive coefficient on $\beta_{3}$.

Panel A of Table 5 presents a univariate analysis comparing mean Tobin's $q$ before and after the board reforms for the treatment sample and the benchmark PSM-U.K. sample. For the major board reform, the panel shows that mean Tobin's $q$ increases from 1.576 to 1.871 for the treatment sample. In addition, the difference is significant at $p \leq 0.01$ (two-tailed). The panel also indicates that the increase in Tobin's $q$ for the treatment sample is significantly larger than the increase in Tobin's $q$ for the benchmark PSM-U.K. sample. We find the similar pattern for the first board reform.

Panel B of Table 5 presents the regression results. Columns (1) and (2) report the results for the major reforms, and Columns (3) and (4) report the results for the first reforms. Columns (1) and (3) present the estimated results of Eq. (2) and columns (2) and (4) present the results of an alternative model after replacing the dummy variables Post and Treatment with country and year fixed effects. ${ }^{13}$ We find the coefficient on the interaction term, Post $\times$ Treatment, is significantly positive in all columns. This result is consistent with our inferences in Table 4 and suggests that firm value increases subsequent to board reforms.

\section{Effects of Major Components of Board Reforms on Firm Value}

This section examines how the intensity and the individual components of board reforms affect firm value. We assess the effect of the intensity of reforms by recoding the indicator Post

\footnotetext{
${ }^{13}$ We suppress the coefficient on the dummy variable indicating treatment firms, Treatment, because it is a linear combination of country fixed effects. We suppress the coefficient on the dummy variable indicating post period, Post, because this coefficient is not interpretable with the inclusion of year fixed effects. Our results are not sensitive to including the dummy variables indicating post periods.
} 
to equal one if a firm-year falls on or after the enactment of a reform with greater impact, defined as reforms involving at least two of the three major components reported in Table 1: (1) board independence, (2) audit committee and auditor appointment, and (3) CEO and chairman duality. We assess the effect of an individual component of reforms by re-estimating Eq. (1) after restricting the sample to countries with reforms involving the individual component that is being examined. This way, we avoid benchmarking with countries that may involve other components of reforms. We then set Post to equal to one starting the year in which the reform involving the individual component becomes effective.

Panel A of Table 6 reports the result for reforms involving greater impact on board structure and reforms involving individual board-related component. Column (1) shows that the coefficient on Post, 0.153, is more than twice as large as the corresponding coefficient reported in Column (2) of Table 4, Panel A, 0.065. This finding suggests that stronger reforms (i.e., reforms with more governance changes) lead to greater increases in firm value. In addition, the panel shows that on average, reforms involving the individual components increase firm value.

For completeness, we also perform analysis exploring the effect of non-board components of the reform. We perform this analysis by adding two more post dummies in addition to the post dummy indicating periods subsequent to the enactment of reforms with greater impact (i.e., reforms with at least two governance characteristics): a post dummy indicating periods subsequent to the enactment of reforms with one governance characteristics, and another post dummy indicating periods subsequent to the enactment of reforms with additional non-board component. Panel B of Table 6 reports the results of this analysis. It finds weak evidence that reforms including non-board components have incremental effects beyond 
reforms with governance characteristics. Importantly, we continue to find that reforms with greater impact on board structures lea to greater increase in firm value.

\section{Test of Hypothesis 2}

\section{Ex ante Legal Institutions and the Effect of Board Reforms}

Our second hypothesis predicts that firm values increase more in countries with weaker ex ante institutional quality following enactment of the reforms. To test this hypothesis, we estimate Eq. (1) and interact Post with three variables indicating poor institutional quality: Low Rule of Law, Low Disclosure, and Code Law. Low Rule of Law is equal to one if a country's rule of law index from Kaufmann et al. (2009) as of year $t$ is below the country-level median and zero otherwise. Low Disclosure is equal to one if a country's disclosure requirement index from La Porta et al. (2006) is below the country-level median and zero otherwise. Code Law is equal to one if the country has a Code Law legal origin.

In Table 7, Columns (1) through (3) report the results of this analysis for the major reforms, and Columns (4) through (6) report the results for the first reforms. The coefficients on Post are insignificant in all specifications, suggesting that the reforms have little effect in countries with strong legal institutions. The coefficients on the interaction terms, Post x Low Rule of Law, Post x Low Disclosure, and Post x Code Law, are statistically positive in all specifications. As an example of economic significance, the result in Column (1) indicates that Tobin's $q$ increases by $7.2 \%$ in countries with Low Rule of Law after the major board reform. ${ }^{14}$ Overall, these findings are consistent with Hypothesis 2 and suggest that the increase in $q$ after the reform is higher in countries with weaker institutional quality.

\section{The Role of Firm-level Governance and Information Environments}

\footnotetext{
$147.2 \%=(0.019+0.100) / 1.65$, where 0.019 and 0.100 are $\beta_{1}$ and $\beta_{2}$ in Column (1) of Table 5, and 1.65 is the mean Tobin's $q$ in Panel A of Table 3.
} 
To provide further corroborating evidence for Hypothesis 2 that firm values increases more in countries with weaker ex ante institutional quality following the enactment of board reforms, we examine the effects of reforms conditional on firm-level governance characteristics and information environments. When developing our second hypothesis, we reason that firms in countries with weaker institutional quality may stand to gain more from board reforms. We also expect firms with weaker ex ante governance practices or greater information asymmetry to benefit more from board reforms because these factors tend to be associated with greater agency problems.

We measure firm-level governance (Governance) using the governance index in Aggarwal et al. (2011). Our sample size thus is greatly reduced, because the data are available only for 21 of our 41 sample countries and for a subset of sample firms in these countries. We use two proxies for information asymmetry: analyst coverage (Coverage) and forecast dispersion (Forecast Dispersion). Appendix B provides definitions of these variables. We then create three indicator variables that capture low firm-level governance quality and poor information environments: (1) Low Governance and Low Coverage, which equal one if a firm's governance index and analyst coverage is below the median in its country, respectively, and (2) High Forecast Dispersion, which equals one if a firm's forecast dispersion is above the median in its country.

Table 8 shows that the coefficients on the interaction between Post and the variable indicating low firm-level governance and poor information environments are significantly positive in all columns. These findings are consistent with our predictions and suggest that the valuation impact of board reforms is more pronounced for firms with weaker firm-level governance quality and poorer information environments. 


\section{ADDITIONAL ANALYSES AND SENSITIVITY TESTS}

\section{Comply-or-explain Versus Regulation Reforms}

Countries differ in the way in which they conduct board reforms. Some rely on regulation reforms, while others prefer the comply-or-explain approach. Regulators need to decide on the reform type when launching the reforms. Thus, this subsection explores how the valuation increases associated with board reforms vary across different types of reforms.

We perform this analysis by estimating Eq. (1) separately for comply-or-explain reforms and regulation reforms. Panels A and B of Table 9 present the results for the comply-or-explain and the regulation reforms, respectively. Columns (1) and (2) cover the major reforms; Columns (3) and (4), the first reforms. Panel A shows that comply-or-explain reforms on average are positively associated with increases in firm value, but the effect does not vary with ex ante institutional quality. Panel B shows that regulation reforms on average are not associated with increases in firm value, but the effect increases with weak institutional quality. These findings indicate that, on average, the positive effect of board reforms is concentrated among comply-orexplain reforms. In addition, firms in countries with weaker institutional quality benefit more from regulation reforms, but not from comply-or-explain reforms. Overall, in contrast to the impact of one-size-fits-all regulations, the flexibility inherent in comply-or-explain reforms may encourage firms to adopt better governance standards that enhance their value, without being forced to adopt excessively costly provisions.

The Impact of Board reforms on Operating Performance, Reporting Quality, and Investment-Cash Flow Sensitivity

This subsection examines the effect of board reforms on operating performance, reporting quality, and investment-cash flow sensitivity. If board reforms are beneficial, we expect them to 
be associated with improved operating performance and reporting quality. In addition, if board reforms improve investor protection, we expect that firms with low cash flows find it easier and less costly to raise external capital after enactment of the reform, which in turn makes investment less sensitive to cash flows. Consequently, if board reforms are beneficial, we expect a reduction in investment-cash flow sensitivity following the reform.

We capture operating performance using two measures of firm profitability: return on assets $(R O A)$ and return on equity $(R O E)$. For reporting quality, we use the absolute level of discretionary accruals $(|D A C C|)$. Higher absolute discretionary accruals capture insiders' propensity to overstate and understate reported income to conceal resource diversion and mask true performance, and thus indicate lower reporting quality. We then test the effect of board reforms on operating performance and reporting quality by re-estimate Eq. (1) after using ROA, $\mathrm{ROE}$, and $\mid \mathrm{DACCl}$ as the dependent variable. In the regression of ROA and ROE, we also replace the control variable industry Tobin's $q$ with Industry ROA and Industry ROE. Panel A of Table 10 presents the results. We find that the coefficient on Post is significantly positive in all the regressions of firm profitability, and is significantly negative in the regression of reporting quality for the major reforms. These results suggest that firm profitability and reporting quality improve after the board reforms, corroborating our primary findings on firm value.

To test the effect of board reforms on investment-cash flow sensitivity, we following McLean et al. (2012) and estimate the regressions

$$
\begin{aligned}
\frac{I N V_{i, t}}{A_{i, t-1}}=\alpha_{c}+\beta_{t}+ & \gamma_{j}+\beta_{1} \text { Post }_{c t}+\beta_{2} \text { Post }_{c t} \times \frac{\text { Cash Flow }_{i, t-1}}{A_{i, t-1}}+\beta_{3} q_{t-1}+\beta_{4} \frac{\text { Cash Flow }_{i, t-1}}{A_{i, t-1}} \\
& +\beta_{5} G D P \times q_{t-1}+\beta_{6} G D P \times \frac{\text { Cash Flow }_{i, t-1}}{A_{i, t-1}}+\varepsilon_{i, t}
\end{aligned}
$$


$I N V_{i, t}$ is investment of firm $i$ in year $t$, measured as capital expenditure. Cash Flow equals net income before extraordinary items minus accruals. Following the literature, we scale $I N V$ and Cash Flow by the lagged book value of assets. $\alpha_{c}, \beta_{t}$, and $\gamma_{\mathrm{j}}$ are year, country, and industry fixed effects, respectively. As in prior analyses, we cluster the standard errors at the country level.

Panel B of Table 10 reports the results. Columns (1) and (3) show the results from the estimation of Eq. (3) for the major reforms and the first reforms, respectively. Columns (2) and (4) test the robustness of the results using an alternate measure of investment, the annual growth in total assets. Confirming prior research, we find the coefficients on cash flows to be significant and positive in all columns. In addition, the coefficients on the interaction term, Post $\mathrm{x}$ Cash Flow, are significantly negative in all columns. This result is consistent with our prediction and suggests a significant reduction in investment-cash flow sensitivity following the board reforms.

\section{Additional Robustness Checks}

Table 2 shows that U.S. firms account for $30 \%$ of our sample. To ensure that our results are not driven by the U.S., we repeat our analyses in Table 4, Panel A, and Table 5 after excluding U.S. firms. Panels A and B of Table 11 present the results for the major reform and the first reform, respectively. Columns (1) and (2) of Table 11 show that our results continue to hold. We also use the market-to-book of equity as an alternate proxy for firm value. The results, in Columns (3) and (4), confirm our primary findings using Tobin's $q$.

\section{CONCLUSION}

In this paper, we take a first step at analyzing the valuation impact of board reforms around the world. Board reforms have positive valuation consequences, and the effect is greater among firms in countries with weaker ex ante institutional quality. Furthermore, the effect of 
reforms is concentrated among comply-or-explain reforms, and the role of country-level institutions is less important for these reforms than for regulation reforms. In addition, firms' profitability improves and investment-cash flow sensitivity declines after implementation of the board reforms.

Overall, our results suggest that exogenously imposed governance changes benefit shareholders, but mainly in countries with poor institutional quality and for reforms with a comply-or-explain instead of a regulation approach. 


\section{References}

Aggarwal, R., I. Erel, M. Ferreira, and P. Matos. 2011. Does governance travel around the world? Evidence from institutional investors. Journal of Financial Economics 100, 154181.

Aggarwal, R., I. Erel, R. Stulz, and R. Williamson. 2009. Differences in governance practices between U.S. and foreign firms: Measurement, causes, and consequences. Review of Financial Studies 22, 3131-3169.

Aghion, P. and B. Hermalin. 1990. Legal restrictions on private contracts can enhance efficiency. Journal of Law, Economics, and Organization 6, 381-409.

Aguilera, R., and A. Cuervo-Cazurra. 2004. Codes of good governance worldwide: What is the trigger? Studies in Organizational Management 25, 415-443.

Anderson, R.C., S.A. Mansi, and D.M. Reeb. 2004. Board characteristics, accounting report integrity, and the cost of debt. Journal of Accounting and Economics 37: 315-342.

Bertrand, M., and S. Mullainathan. 2003. Enjoying the quiet life? Corporate governance and managerial preferences. Journal of Political Economy 111, 1043-1075.

Black, B.S., and V.S. Khanna. 2007. Can corporate governance reforms increase firm market values? Event study evidence from India. Journal of Empirical Legal Studies 4, 749-796.

Black, B.S., and W. Kim. 2012. The effect of board structure on firm value: A multiple identification strategies approach using Korean data. Journal of Financial Economic 104, 203-226.

Chhaochharia, and V., Grinstein, Y. 2007. Corporate governance and firm value: The impact of the 2002 governance rules. Journal of Finance 62, 1789-1825.

Cicon, J., S.P. Ferris, J. Kammel, and G. Nonronha. 2012. European corporate governance: A thematic analysis of national codes of governance. European Financial Management 18, 620-648.

Dahya, J., and J. J. McConnell. 2007. Board composition, corporate performance, and the Cadbury Committee recommendation. Journal of Financial and Quantitative Analysis 42, 535-564.

DeFond, M. and M. Hung. 2004. Investor protection and corporate governance: Evidence from worldwide CEO turnover. Journal of Accounting Research 42, 269-312. 
DeFond, M., X. Hu, M. Hung, and S. Li. 2011. The impact of mandatory IFRS adoption on foreign mutual fund ownership: The role of comparability. Journal of Accounting and Economics 51, 240-258.

Denis, D. and J. McConnell. 2003. International corporate governance. Journal of Financial and Quantitative Analysis 38, 1-36.

Doidge, C., G.A. Karolyi, and R. Stulz. 2004. Why are foreign firms listed in the U.S. worth more? Journal of Financial Economics 71, 205-238.

Gompers, P.A., J. Ishii, and A. Metrick. 2010. Extreme governance: An analysis of dual-class firms in the United States. Review of Financial Studies 23, 1051-1088.

Griffin, J.M., P.J. Kelly, and F. Nardari. 2010. Do market efficiency measures yield correct inferences? A comparison of developed and emerging markets. Review of Financial Studies 23, 3225-3277.

Hail, L., A. Tahoun, and C. Wang. 2014 Dividend payouts and information shocks. Journal of Accounting Research 52, 403-456.

Harris, M., and A. Raviv. 2008. A theory of board control and size. Review of Financial Studies $21,1797-1832$.

Hermalin, B., and M. Weisbach. 2003. Boards of directors as an endogenously determined institution: A survey of the economic literature. FRBNY Economic Policy Review 9, 7 26.

Ince, O.S., and R.B. Porter. 2006. Individual equity return data from Thomson DataStream: Handle with care! Journal of Financial Research 29, 463-479.

Jensen, M.C., and W.H. Meckling. 1976. Theory of the firm: Managerial behavior, agency costs, and ownership structure. Journal of Financial Economics 3, 305-360.

Kaufmann, D., A. Kraay, and M. Mastruzzi. 2009. Governance matters VIII: Aggregate and individual governance indicators 1996-2008. Working Paper, World Bank.

Kim, E.H., and Y. Lu. 2013. Corporate governance reforms around the world and cross-border acquisitions. Journal of Corporate Finance 22, 236-253.

La Porta, R., F. Lopez De Silanes, and A. Shleifer. 2006. What works in securities laws? Journal of Finance 61, 1-33.

La Porta, R., F. Lopez-de-Silanes, A. Shleifer, and R. Vishny. 1997. Legal determinants of external finance. Journal of Finance 52, 1131-1150. 
La Porta, R., F. Lopez-de-Silanes, A. Shleifer, and R. Vishny. 1998. Law and finance. Journal of Political Economy 106, 1113-1155.

La Porta, R., F. Lopez-De-Silanes, A. Shleifer, A., and R. Vishny. 2002. Investor protection and corporate valuation. Journal of Finance 57, 1147-1170.

Li, X. 2014. The Sarbanes-Oxley Act and foreign private issuers. Journal of Accounting and Economics 58, 21-40.

McLean, R.D., T. Zhang, and M. Zhao. 2012. Why does the law matter? Investor protection and its effects on investment, finance, and growth. Journal of Finance 68, 313-350.

North, D., 1990. Institutions, Institutional Change, and Economic Performance. Cambridge University Press, Cambridge, U.K.

Salterio, S., J. Conrod, and R. Schmidt. 2013. Canadian evidence of adherence to "Comply or Explain" corporate governance codes: An international comparison. Accounting Perspectives 12, 23-51.

Srinivasan, S., A. Wahid, and G. Yu. 2014. Admitting mistakes: Home country effect on the reliability of restatement reporting. The Accounting Review forthcoming.

Wintoki, M.B., J. Linck, and J. Netter. 2012. Endogeneity and the dynamics of internal corporate governance. Journal of Financial Economics 105, 581-606.

Wooldridge, J. 2002. Econometric Analysis of Cross Section and Panel Data. MIT press. MA.

Wooldridge, J. 2007. Difference-in-differences Estimation. NBER.

Zhang, I.X., 2007. Economic consequences of the Sarbanes-Oxley Act of 2002. Journal of Accounting and Economics 44, 74-115. 
TABLE 1

Board reforms Worldwide

The table reports the year of board reform, key components, and type of the reform by country. Panel A describes the major reform, and Panel B describes the first reform. Appendix A provides detailed information about the reforms.

\section{Panel A: Major Board Reform}

\begin{tabular}{|c|c|c|c|c|c|c|}
\hline Country & $\begin{array}{c}\text { Reform } \\
\text { year }\end{array}$ & $\begin{array}{c}\text { Board } \\
\text { independence } \\
\end{array}$ & $\begin{array}{c}\text { Audit } \\
\text { committee } \\
\text { or auditor }\end{array}$ & $\begin{array}{c}\text { CEO and } \\
\text { chairman role }\end{array}$ & $\begin{array}{c}\text { Non-board- } \\
\text { related } \\
\text { component }\end{array}$ & Type \\
\hline Argentina & 2001 & 0 & 1 & 0 & 1 & Regulation \\
\hline Australia & 2004 & 1 & 1 & 1 & 1 & Comply-or-explain \\
\hline Austria & 2004 & 1 & 1 & 0 & 1 & Comply-or-explain \\
\hline Belgium & 2005 & 1 & 1 & 1 & 1 & Comply-or-explain \\
\hline Brazil & 2002 & 0 & 0 & 0 & 1 & Regulation \\
\hline Canada & 2004 & 1 & 1 & 1 & 0 & Regulation \\
\hline Chile & 2001 & 0 & 1 & 0 & 1 & Regulation \\
\hline China & 2001 & 1 & 1 & 0 & 1 & Regulation \\
\hline Colombia & 2001 & 0 & 0 & 0 & 1 & Regulation \\
\hline Czech Republic & 2001 & 0 & 0 & 0 & 1 & Regulation \\
\hline Denmark & 2001 & 1 & 0 & 0 & 1 & Comply-or-explain \\
\hline Egypt & 2002 & 1 & 1 & 0 & 1 & Regulation \\
\hline Finland & 2004 & 1 & 1 & 1 & 1 & Comply-or-explain \\
\hline France & 2003 & 0 & 1 & 0 & 1 & Regulation \\
\hline Germany & 2002 & 1 & 1 & 0 & 1 & Comply-or-explain \\
\hline Greece & 2002 & 1 & 1 & 0 & 0 & Regulation \\
\hline Hong Kong & 2005 & 1 & 1 & 1 & 0 & Comply-or-explain \\
\hline Hungary & 2003 & 0 & 0 & 0 & 0 & Comply-or-explain \\
\hline India & 2002 & 1 & 1 & 0 & 1 & Regulation \\
\hline Indonesia & 2007 & 1 & 1 & 0 & 0 & Regulation \\
\hline Israel & 2000 & 1 & 1 & 1 & 1 & Regulation \\
\hline Italy & 2006 & 1 & 1 & 0 & 1 & Regulation \\
\hline Japan & 2002 & 1 & 1 & 0 & 0 & Regulation \\
\hline Malaysia & 2001 & 1 & 1 & 0 & 0 & Comply-or-explain \\
\hline Mexico & 2001 & 1 & 1 & 0 & 1 & Regulation \\
\hline Netherlands & 2004 & 1 & 1 & 1 & 0 & Comply-or-explain \\
\hline Norway & 2005 & 1 & 1 & 1 & 1 & Comply-or-explain \\
\hline Pakistan & 2002 & 0 & 1 & 0 & 0 & Comply-or-explain \\
\hline Peru & 2005 & 1 & 1 & 0 & 0 & Comply-or-explain \\
\hline Philippines & 2002 & 1 & 1 & 0 & 1 & Comply-or-explain \\
\hline Poland & 2002 & 1 & 0 & 0 & 1 & Comply-or-explain \\
\hline Portugal & 2001 & 1 & 1 & 0 & 0 & Regulation \\
\hline Singapore & 2003 & 1 & 1 & 0 & 1 & Comply-or-explain \\
\hline South Korea & 1999 & 1 & 1 & 0 & 1 & Regulation \\
\hline Spain & 2006 & 1 & 1 & 0 & 1 & Comply-or-explain \\
\hline Sweden & 2006 & 1 & 1 & 1 & 1 & Comply-or-explain \\
\hline Switzerland & 2002 & 0 & 0 & 0 & 1 & Comply-or-explain \\
\hline Thailand & 2002 & 1 & 1 & 0 & 1 & Comply-or-explain \\
\hline Turkey & 2002 & 1 & 0 & 1 & 1 & Comply-or-explain \\
\hline U.K. & 1998 & 1 & 1 & 1 & 1 & Comply-or-explain \\
\hline U.S. & 2003 & 1 & 1 & 0 & 1 & Regulation \\
\hline
\end{tabular}


TABLE 1, CONTINUED

Panel B: First Board Reform

\begin{tabular}{|c|c|c|c|c|c|c|}
\hline Country & $\begin{array}{c}\text { Reform } \\
\text { year }\end{array}$ & $\begin{array}{c}\text { Board } \\
\text { independence }\end{array}$ & $\begin{array}{c}\text { Audit } \\
\text { committee } \\
\text { or auditor }\end{array}$ & $\begin{array}{c}\text { CEO and } \\
\text { chairman role }\end{array}$ & $\begin{array}{l}\text { Non-board- } \\
\text { related } \\
\text { components }\end{array}$ & Type \\
\hline Argentina & 2001 & 0 & 1 & 0 & 1 & Regulation \\
\hline Australia & 2003 & 1 & 1 & 0 & 1 & Comply-or-explain \\
\hline Austria & 2002 & 1 & 1 & 0 & 1 & Comply-or-explain \\
\hline Belgium & 1998 & 1 & 0 & 0 & 1 & Comply-or-explain \\
\hline Brazil & 2002 & 0 & 0 & 0 & 1 & Regulation \\
\hline Canada & 2004 & 1 & 1 & 1 & 0 & Regulation \\
\hline Chile & 2001 & 0 & 1 & 0 & 1 & Regulation \\
\hline China & 2001 & 1 & 1 & 0 & 1 & Regulation \\
\hline Colombia & 2001 & 0 & 0 & 0 & 1 & Regulation \\
\hline Czech Republic & 2001 & 0 & 0 & 0 & 1 & Regulation \\
\hline Denmark & 2001 & 1 & 0 & 0 & 1 & Comply-or-explain \\
\hline Egypt & 2002 & 1 & 1 & 0 & 1 & Regulation \\
\hline Finland & 2003 & 1 & 1 & 0 & 1 & Comply-or-explain \\
\hline France & 2001 & 0 & 0 & 1 & 1 & Regulation \\
\hline Germany & 2002 & 1 & 1 & 0 & 1 & Comply-or-explain \\
\hline Greece & 1999 & 0 & 0 & 0 & 1 & Comply-or-explain \\
\hline Hong Kong & 2005 & 1 & 1 & 1 & 0 & Comply-or-explain \\
\hline Hungary & 2003 & 0 & 0 & 0 & 0 & Comply-or-explain \\
\hline India & 1998 & 0 & 0 & 0 & 1 & Comply-or-explain \\
\hline Indonesia & 2000 & 1 & 0 & 0 & 1 & Comply-or-explain \\
\hline Israel & 2000 & 1 & 1 & 1 & 1 & Regulation \\
\hline Italy & 2006 & 1 & 1 & 0 & 1 & Regulation \\
\hline Japan & 2002 & 1 & 1 & 0 & 0 & Regulation \\
\hline Malaysia & 2001 & 1 & 1 & 0 & 0 & Comply-or-explain \\
\hline Mexico & 1999 & 1 & 1 & 0 & 1 & Comply-or-explain \\
\hline Netherlands & 1997 & 0 & 0 & 0 & 1 & Comply-or-explain \\
\hline Norway & 2005 & 1 & 1 & 1 & 1 & Comply-or-explain \\
\hline Pakistan & 2002 & 0 & 1 & 0 & 0 & Comply-or-explain \\
\hline Peru & 2002 & 1 & 1 & 1 & 0 & Comply-or-explain \\
\hline Philippines & 2002 & 1 & 1 & 0 & 1 & Comply-or-explain \\
\hline Poland & 2002 & 1 & 0 & 0 & 1 & Comply-or-explain \\
\hline Portugal & 1999 & 0 & 0 & 0 & 1 & Comply-or-explain \\
\hline Singapore & 2003 & 1 & 1 & 0 & 1 & Comply-or-explain \\
\hline South Korea & 1999 & 1 & 1 & 0 & 1 & Regulation \\
\hline Spain & 1998 & 0 & 1 & 0 & 1 & Comply-or-explain \\
\hline Sweden & 2005 & 1 & 1 & 1 & 0 & Regulation \\
\hline Switzerland & 2002 & 0 & 0 & 0 & 1 & Comply-or-explain \\
\hline Thailand & 2002 & 1 & 1 & 0 & 1 & Comply-or-explain \\
\hline Turkey & 1999 & 0 & 0 & 0 & 1 & Regulation \\
\hline U.K. & 1992 & 1 & 1 & 1 & 1 & Comply-or-explain \\
\hline U.S. & 2003 & 1 & 1 & 0 & 1 & Regulation \\
\hline
\end{tabular}


TABLE 2

Sample Distribution

The table shows the sample distribution by country. The start year is either 1990 or the first year in which WorldScope has data available on total assets and market value for at least ten firms.

\begin{tabular}{|c|c|c|c|}
\hline Country & Start year & Number of firms & Number of firm-years \\
\hline Argentina & 1992 & 71 & 500 \\
\hline Australia & 1990 & 1,863 & 8,899 \\
\hline Austria & 1990 & 113 & 908 \\
\hline Belgium & 1990 & 146 & 690 \\
\hline Brazil & 1994 & 107 & 565 \\
\hline Canada & 1990 & 1,560 & 5,166 \\
\hline Chile & 1990 & 154 & 1,320 \\
\hline China & 1993 & 1,809 & 3,532 \\
\hline Colombia & 1992 & 44 & 257 \\
\hline Czech Republic & 1995 & 52 & 153 \\
\hline Denmark & 1990 & 230 & 2,202 \\
\hline Egypt & 2000 & 90 & 418 \\
\hline Finland & 1990 & 181 & 1,771 \\
\hline France & 1990 & 1,054 & 8,006 \\
\hline Germany & 1990 & 877 & 6,673 \\
\hline Greece & 1990 & 287 & 1,145 \\
\hline Hong Kong & 1990 & 1,032 & 7,895 \\
\hline Hungary & 1995 & 42 & 259 \\
\hline India & 1991 & 1,134 & 8,215 \\
\hline Indonesia & 1991 & 319 & 2,952 \\
\hline Israel & 1992 & 304 & 758 \\
\hline Italy & 1990 & 357 & 3,222 \\
\hline Japan & 1990 & 2,782 & 24,936 \\
\hline Malaysia & 1990 & 791 & 7,487 \\
\hline Mexico & 1990 & 159 & 583 \\
\hline Netherlands & 1990 & 208 & 2,149 \\
\hline Norway & 1990 & 359 & 1,956 \\
\hline Pakistan & 1992 & 137 & 823 \\
\hline Peru & 1992 & 107 & 491 \\
\hline Philippines & 1991 & 163 & 1,366 \\
\hline Poland & 1995 & 243 & 436 \\
\hline Portugal & 1990 & 81 & 573 \\
\hline Singapore & 1990 & 628 & 4,883 \\
\hline South Korea & 1990 & 770 & 6,463 \\
\hline Spain & 1990 & 151 & 1,586 \\
\hline Sweden & 1990 & 634 & 3,300 \\
\hline Switzerland & 1990 & 282 & 3,011 \\
\hline Thailand & 1990 & 460 & 4,249 \\
\hline Turkey & 1990 & 250 & 1,987 \\
\hline U.K. & 1990 & 2,911 & 22,943 \\
\hline U.S. & 1990 & 9,714 & 41,288 \\
\hline Total & & 32,656 & 196,016 \\
\hline
\end{tabular}


TABLE 3

Descriptive Statistics and Correlations

Panel A shows descriptive statistics, and Panel B shows correlation among variables. * indicates that the correlation is significant at least at the $10 \%$ level. Appendix B provides definitions of variables.

\section{Panel A: Descriptive Statistics}

\begin{tabular}{lcccccc}
\hline Variables & $\begin{array}{c}\text { Number of } \\
\text { observations }\end{array}$ & Mean & Quintile 1 & Median & Quintile 3 & $\begin{array}{c}\text { Standard } \\
\text { deviation }\end{array}$ \\
\hline Firm-level variables & 196,016 & 1.65 & 0.91 & 1.17 & 1.75 & 1.55 \\
Tobin's $q$ & & & & & & \\
Size (millions of & 196,016 & 255 & 66 & 236 & 900 & 0.01 \\
dollars) & 196,016 & 2.65 & 2.08 & 2.71 & 3.18 & 0.94 \\
Age & 196,016 & 0.21 & 0.04 & 0.19 & 0.34 & 0.18 \\
Leverage & 196,016 & 0.10 & 0.02 & 0.06 & 0.13 & 0.13 \\
Cash & 196,016 & 0.66 & 0.12 & 0.27 & 0.59 & 1.33 \\
PPE & 196,016 & 0.20 & 0.00 & 0.00 & 0.35 & 0.29 \\
Foreign Sales & 196,016 & 0.05 & 0.00 & 0.00 & 0.01 & 0.20 \\
R\&D & 196,016 & 0.07 & 0.02 & 0.04 & 0.08 & 0.09 \\
Capex & 196,016 & 0.39 & 0.16 & 0.39 & 0.60 & 0.27 \\
Closely Held & 196,016 & 0.06 & 0.00 & 0.00 & 0.00 & 0.23 \\
ADR & & & & & & \\
Country-level & & & & & & \\
variables & 41 & 9.94 & 10.22 & 10.44 & 10.48 & 1.01 \\
Log GDP & 41 & 0.03 & 0.02 & 0.02 & 0.04 & 0.04 \\
FDI & 41 & 1.25 & 1.33 & 1.55 & 1.62 & 0.65 \\
Rule of Law & 37 & 0.82 & 0.75 & 0.83 & 1.00 & 0.19 \\
Disclosure & 41 & 0.42 & 0.00 & 0.00 & 1.00 & 0.49 \\
Code Law & & & & & & \\
Time trend variable & 196,016 & 1.36 & 1.01 & 1.23 & 1.58 & 0.47 \\
Industry q & & & & & & \\
\hline
\end{tabular}




\section{TABLE 3, CONTINUED}

\section{Panel B: Correlations}

\begin{tabular}{|c|c|c|c|c|c|c|c|c|c|c|c|c|c|c|c|c|c|}
\hline & & (1) & $(2)$ & (3) & (4) & (5) & (6) & (7) & (8) & (9) & (10) & (11) & (12) & (13) & (14) & (15) & $(16)$ \\
\hline (1) & Tobin's q & 1 & & & & & & & & & & & & & & & \\
\hline (2) & Size & $-0.173^{*}$ & 1 & & & & & & & & & & & & & & \\
\hline (3) & Age & $-0.100 *$ & $0.237 *$ & 1 & & & & & & & & & & & & & \\
\hline (4) & Leverage & $-0.200^{*}$ & $0.249^{*}$ & $0.027 *$ & 1 & & & & & & & & & & & & \\
\hline (5) & Cash & $0.256^{*}$ & $-0.183^{*}$ & $-0.094 *$ & $-0.323^{*}$ & 1 & & & & & & & & & & & \\
\hline (6) & $\begin{array}{l}\text { PPE } \\
\text { Foreign }\end{array}$ & 0.001 & $-0.026^{*}$ & $-0.028^{*}$ & $0.111^{*}$ & $-0.061^{*}$ & 1 & & & & & & & & & & \\
\hline (7) & Sales & $-0.017 *$ & $0.210^{*}$ & $0.076^{*}$ & $-0.027 *$ & $0.062 *$ & $-0.053 *$ & 1 & & & & & & & & & \\
\hline (8) & $R \& D$ & $0.243^{*}$ & $-0.151^{*}$ & $-0.082 *$ & $-0.146^{*}$ & $0.260^{*}$ & $0.100^{*}$ & $0.010^{*}$ & 1 & & & & & & & & \\
\hline (9) & Capex & $0.095^{*}$ & $0.017^{*}$ & $-0.095^{*}$ & $0.100^{*}$ & $-0.075^{*}$ & $0.242 *$ & $-0.046^{*}$ & $-0.053 *$ & 1 & & & & & & & \\
\hline (10) & Closely Held & $-0.060 *$ & $-0.140^{*}$ & $-0.085^{*}$ & 0.000 & $-0.030 *$ & $-0.013^{*}$ & $-0.066^{*}$ & $-0.115^{*}$ & $-0.017 *$ & 1 & & & & & & \\
\hline (11) & $A D R$ & $-0.006^{*}$ & $0.279 *$ & $0.092 *$ & $0.041 *$ & $-0.010^{*}$ & $0.017 *$ & $0.166^{*}$ & 0.003 & -0.000 & $-0.062 *$ & 1 & & & & & \\
\hline (12) & $\log G D P$ & $0.035^{*}$ & $0.108^{*}$ & $0.007 *$ & $-0.136^{*}$ & $0.216^{*}$ & $-0.081 *$ & $0.236^{*}$ & $0.127 *$ & $-0.084 *$ & $-0.136^{*}$ & $0.054 *$ & 1 & & & & \\
\hline (13) & $F D I$ & -0.002 & $-0.074 *$ & $-0.041^{*}$ & $-0.061 *$ & $0.073^{*}$ & $0.039 *$ & $0.218^{*}$ & $-0.039 *$ & -0.004 & $0.135^{*}$ & $0.045^{*}$ & $0.078^{*}$ & 1 & & & \\
\hline (15) & Disclosure & $0.147 *$ & $-0.150 *$ & $0.022 *$ & $-0.104 *$ & $0.112 *$ & $0.035^{*}$ & $-0.074 *$ & $0.134 *$ & $0.017 *$ & $-0.157 *$ & $-0.090^{*}$ & $0.057 *$ & $0.124 *$ & $0.138^{*}$ & 1 & \\
\hline (16) & Code Law & $-0.167 *$ & $0.299 *$ & $0.013^{*}$ & $0.138^{*}$ & $-0.064 *$ & $-0.076^{*}$ & -0.002 & $-0.129 *$ & $-0.070^{*}$ & $0.154 *$ & $0.067 *$ & $0.014 *$ & $-0.227^{*}$ & $-0.172 *$ & $-0.774 *$ & 1 \\
\hline (17) & Industry $q$ & $0.382 *$ & $-0.125^{*}$ & $-0.040 *$ & $-0.150 *$ & $0.164 *$ & $0.019^{*}$ & $-0.016^{*}$ & $0.241 *$ & $0.066^{*}$ & $-0.131 *$ & $-0.043^{*}$ & $0.072 *$ & $-0.051 *$ & $0.116^{*}$ & $0.306^{*}$ & $-0.327 *$ \\
\hline
\end{tabular}


TABLE 4

Board reforms and Firm Value

Panel A presents the regression results of the impact of board reforms on Tobin's $q$. Panel B reports results based on alternative specifications. $t$-statistics, in parentheses, are based on standard errors clustered at the country level. *,**, and *** indicate significance at the 10\%, 5\%, and 1\% two-tailed level, respectively. See Appendix $\mathrm{B}$ for variable definitions.

Panel A: Board Reforms and Firm Value

\begin{tabular}{|c|c|c|c|c|}
\hline \multirow[b]{2}{*}{ Variables } & \multicolumn{2}{|c|}{ Major reform } & \multicolumn{2}{|c|}{ First reform } \\
\hline & (1) & $(2)$ & (3) & (4) \\
\hline Post & $\begin{array}{l}\mathbf{0 . 1 1 3}^{* *} \\
(2.07)\end{array}$ & $\begin{array}{l}\mathbf{0 . 0 6 5}^{* *} \\
(2.38)\end{array}$ & $\begin{array}{l}\mathbf{0 . 1 2 2} * * * \\
(3.07)\end{array}$ & $\begin{array}{l}\mathbf{0 . 0 6 5}^{* * * *} \\
(3.59)\end{array}$ \\
\hline \multicolumn{5}{|l|}{ Firm-level variables } \\
\hline Size & & $\begin{array}{l}-0.060 * * * \\
(-5.06)\end{array}$ & & $\begin{array}{l}-0.060 \text { *** } \\
(-5.06)\end{array}$ \\
\hline Age & & $\begin{array}{l}-0.052 * * * \\
(-2.80)\end{array}$ & & $\begin{array}{l}-0.052 * * * \\
(-2.82)\end{array}$ \\
\hline Leverage & & $\begin{array}{l}-0.701 * * * \\
(-3.43)\end{array}$ & & $\begin{array}{l}-0.700 * * * \\
(-3.42)\end{array}$ \\
\hline Cash & & $\begin{array}{l}1.782 \text { *** } \\
(15.50)\end{array}$ & & $\begin{array}{l}1.782 \text { *** } \\
(15.52)\end{array}$ \\
\hline$P P E$ & & $\begin{array}{l}-0.022 * * \\
(-2.53)\end{array}$ & & $\begin{array}{l}-0.022^{* *} \\
(-2.53)\end{array}$ \\
\hline Foreign Sales & & $\begin{array}{c}0.043 \\
(1.40)\end{array}$ & & $\begin{array}{c}0.043 \\
(1.40)\end{array}$ \\
\hline$R \& D$ & & $\begin{array}{l}0.858 * * * \\
(11.71)\end{array}$ & & $\begin{array}{l}0.859 \text { *** } \\
(11.54)\end{array}$ \\
\hline Capex & & $\begin{array}{l}1.726^{* * *} \\
(4.45)\end{array}$ & & $\begin{array}{l}1.726^{* * *} \\
(4.45)\end{array}$ \\
\hline Closely Held & & $\begin{array}{l}-0.067 \\
(-0.63)\end{array}$ & & $\begin{array}{c}-0.066 \\
(-0.62)\end{array}$ \\
\hline$A D R$ & & $\begin{array}{l}0.268 * * * \\
(7.66)\end{array}$ & & $\begin{array}{l}0.268 * * * \\
(7.66)\end{array}$ \\
\hline Country-level variables & & & & \\
\hline $\log G D P$ & & $\begin{array}{l}0.115^{*} \\
(1.86)\end{array}$ & & $\begin{array}{l}0.136^{* *} \\
(2.34)\end{array}$ \\
\hline$F D I$ & & $\begin{array}{c}0.212 \\
(0.87)\end{array}$ & & $\begin{array}{c}0.232 \\
(0.96)\end{array}$ \\
\hline $\begin{array}{l}\text { Time trend variables } \\
\text { Industry } q\end{array}$ & & $\begin{array}{l}0.870 * * * \\
(9.52)\end{array}$ & & $\begin{array}{l}0.868 * * * \\
(9.56)\end{array}$ \\
\hline Year fixed effects & yes & yes & yes & yes \\
\hline Country fixed effects & yes & yes & yes & Yes \\
\hline Industry fixed effects & yes & yes & yes & yes \\
\hline Number of observations & 196,016 & 196,016 & 196,016 & 196,016 \\
\hline Adjusted $R^{2}$ & 0.126 & 0.236 & 0.126 & 0.236 \\
\hline
\end{tabular}




\section{TABLE 4, CONTINUED}

Panel B: Board Reforms and Firm Value, Alternative Specifications

\begin{tabular}{|c|c|c|c|c|c|c|c|c|}
\hline \multirow[b]{3}{*}{ Variables } & \multicolumn{2}{|c|}{$\begin{array}{l}\text { Alternative models: } \\
\text { Reform timing variables }\end{array}$} & \multicolumn{2}{|c|}{$\begin{array}{l}\text { Placebo test using pre- } \\
\text { reform years }\end{array}$} & \multicolumn{2}{|c|}{$\begin{array}{l}\text { Placebo test using post- } \\
\text { reform years }\end{array}$} & \multicolumn{2}{|c|}{$\begin{array}{l}\text { Alternative event window: } \\
\qquad[-5,+5]\end{array}$} \\
\hline & $\begin{array}{l}\text { Major } \\
\text { reform }\end{array}$ & $\begin{array}{l}\text { First } \\
\text { reform }\end{array}$ & $\begin{array}{l}\text { Major } \\
\text { reform }\end{array}$ & $\begin{array}{c}\text { First } \\
\text { reform }\end{array}$ & $\begin{array}{l}\text { Major } \\
\text { reform }\end{array}$ & $\begin{array}{c}\text { First } \\
\text { reform }\end{array}$ & $\begin{array}{l}\text { Major } \\
\text { reform }\end{array}$ & $\begin{array}{c}\text { First } \\
\text { reform }\end{array}$ \\
\hline & (1) & (2) & (3) & (4) & (5) & (6) & (7) & (8) \\
\hline Post & & & $\begin{array}{l}-0.008 \\
(-0.17)\end{array}$ & $\begin{array}{l}-0.024 \\
(-0.45)\end{array}$ & $\begin{array}{l}-0.051 \\
(-1.44)\end{array}$ & $\begin{array}{l}-0.009 \\
(-0.11)\end{array}$ & $\begin{array}{l}\text { 0.139** } \\
(2.14)\end{array}$ & $\begin{array}{l}0.167 * * \\
(2.45)\end{array}$ \\
\hline Year -1 & $\begin{array}{l}0.067 \\
(1.25)\end{array}$ & $\begin{array}{r}0.011 \\
(0.28)\end{array}$ & & & & & & \\
\hline Year 0 & $\begin{array}{l}0.092 \\
(1.15)\end{array}$ & $\begin{array}{c}0.064 \\
(0.94)\end{array}$ & & & & & & \\
\hline $\begin{array}{l}\text { Year } 1 \text { (first } \\
\text { enactment year) }\end{array}$ & $\begin{array}{l}0.186^{* *} \\
(2.44)\end{array}$ & $\begin{array}{l}0.188 * * * \\
(2.96)\end{array}$ & & & & & & \\
\hline Year 2+ & $\begin{array}{l}0.146^{*} \\
(1.73)\end{array}$ & $\begin{array}{l}0.160^{* *} \\
(2.66)\end{array}$ & & & & & & \\
\hline $\begin{array}{l}\text { Controls } \\
\text { Fixed effects }\end{array}$ & Yes & Yes & Yes & Yes & Yes & Yes & Yes & Yes \\
\hline included & & & & Year, Co & $\mathrm{y}$, Industry & & & \\
\hline $\begin{array}{l}\text { Number of } \\
\text { observations }\end{array}$ & 196,016 & 196,016 & 79,389 & 67,356 & 106,101 & 118,425 & 107,515 & 99,258 \\
\hline Adjusted $R^{2}$ & 0.218 & 0.219 & 0.223 & 0.225 & 0.224 & 0.223 & 0.225 & 0.226 \\
\hline
\end{tabular}


TABLE 5

\section{Alternative DID Specifications}

This table presents the analysis after beginning the sample period in 2000 and using with PSM-U.K. firms as benchmark. Panel A presents the univariate analysis. Panel B reports regression results. $t$-statistics, in parentheses, are based on standard errors clustered at the country level. *, **, and $* * *$ indicate significance at the $10 \%, 5 \%$, and $1 \%$ two-tailed level, respectively. See Appendix B for variable definitions.

\section{Panel A: Univariate Analysis, $[-5,+5]$ Window}

\begin{tabular}{lcccc}
\hline & \multicolumn{2}{c}{ Major reform } & \multicolumn{2}{c}{ First reform } \\
\hline & $\begin{array}{c}\text { Treatment } \\
\text { (Countries with } \\
\text { reforms > 2000) }\end{array}$ & $\begin{array}{c}\text { Benchmark } \\
\text { (PSM-U.K. } \\
\text { firms) }\end{array}$ & $\begin{array}{c}\text { Treatment } \\
\text { (Countries with } \\
\text { reforms > 2000) }\end{array}$ & $\begin{array}{c}\text { Benchmark } \\
\text { (PSM-U.K. } \\
\text { firms) }\end{array}$ \\
\hline N (firm-years) & 15,414 & 15,414 & 13,331 & 13,331 \\
Pre-period & 1.576 & 1.505 & 1.593 & 1.479 \\
Post-period & 1.871 & 1.765 & 1.913 & 1.783 \\
Change (post-pre) & $0.295^{* * *}$ & $0.260^{* * *}$ & $0.320^{* * *}$ & $0.304 * * *$ \\
Relative change (Treatment-benchmark) & $0.035^{*}$ & & 0.016 & \\
\hline
\end{tabular}

Panel B: Regression Analysis, $[-5,+5]$ Window

\begin{tabular}{|c|c|c|c|c|}
\hline \multirow[b]{2}{*}{ Variables } & \multicolumn{2}{|c|}{ Major reform } & \multicolumn{2}{|c|}{ First reform } \\
\hline & (1) & $(2)$ & (3) & (4) \\
\hline \multirow[t]{2}{*}{ Post } & 0.024 & n.a. & -0.008 & n.a. \\
\hline & $(1.27)$ & & $(-0.34)$ & \\
\hline \multirow[t]{2}{*}{ Treatment } & 0.077 & n.a. & 0.083 & n.a. \\
\hline & $(0.88)$ & & $(1.02)$ & \\
\hline \multirow[t]{2}{*}{ Post $*$ Treatment } & $0.102 *$ & $0.158 * * *$ & $0.118 * *$ & $0.173 * * *$ \\
\hline & $(1.94)$ & $(4.37)$ & $(2.08)$ & (3.96) \\
\hline Controls & yes & yes & yes & yes \\
\hline Year fixed effects & no & yes & no & yes \\
\hline Country fixed effects & no & yes & no & yes \\
\hline Industry fixed effects & yes & yes & yes & yes \\
\hline Number of observations & 127,070 & 127,070 & 101,870 & 101,870 \\
\hline Adjusted $R^{2}$ & 0.183 & 0.200 & 0.189 & 0.204 \\
\hline
\end{tabular}




\section{TABLE 6}

Analysis of Major Components of Board reforms

This table presents the analysis of the impact of individual board structure reforms on Tobin's $q$. Panel A shows the effect of reforms involving at least two board-related components and reforms involving individual board-related component. Panel B shows the effects of board-related component versus additional non-board components. $t$-statistics, in parentheses, are based on standard errors clustered at the country level. *, **, and $* * *$ indicate significance at the $10 \%, 5 \%$, and $1 \%$ two-tailed level, respectively. See Appendix B for variable definitions.

Panel A: The Effect of Board-Related Reform Components

\begin{tabular}{|c|c|c|c|c|c|c|c|c|}
\hline \multirow[b]{3}{*}{ Variables } & \multicolumn{2}{|c|}{$\begin{array}{c}\text { Reforms with Greater } \\
\text { Impact on Boards } \\
\end{array}$} & \multicolumn{2}{|c|}{$\begin{array}{l}\text { Reforms Involving } \\
\text { Board Independence }\end{array}$} & \multicolumn{2}{|c|}{$\begin{array}{l}\text { Reforms Involving Audit } \\
\text { Committee and Auditors }\end{array}$} & \multicolumn{2}{|c|}{$\begin{array}{l}\text { Reforms Involving CEO } \\
\text { and Chairman Duality }\end{array}$} \\
\hline & $\begin{array}{l}\text { Major } \\
\text { reform }\end{array}$ & $\begin{array}{c}\text { First } \\
\text { reform }\end{array}$ & $\begin{array}{l}\text { Major } \\
\text { reform }\end{array}$ & $\begin{array}{c}\text { First } \\
\text { reform }\end{array}$ & $\begin{array}{l}\text { Major } \\
\text { reform }\end{array}$ & $\begin{array}{c}\text { First } \\
\text { reform }\end{array}$ & $\begin{array}{c}\text { Major } \\
\text { reform }\end{array}$ & $\begin{array}{c}\text { First } \\
\text { reform }\end{array}$ \\
\hline & (1) & (2) & (3) & (4) & (5) & (6) & $(7)$ & (8) \\
\hline Post & $\begin{array}{l}0.153 * * * \\
(2.75)\end{array}$ & $\begin{array}{l}0.150 \\
(1.61)\end{array}$ & $\begin{array}{l}0.111 * * \\
(2.28)\end{array}$ & $\begin{array}{l}0.132 * * * * \\
(2.81)\end{array}$ & $\begin{array}{l}0.105 * * \\
(2.18)\end{array}$ & $\begin{array}{l}0.131 * * * \\
(2.88)\end{array}$ & $\begin{array}{l}\text { 0.116* } \\
(1.87)\end{array}$ & $\begin{array}{l}0.211 * * * \\
(3.16)\end{array}$ \\
\hline Controls & Yes & Yes & Yes & Yes & Yes & Yes & Yes & Yes \\
\hline Fixed effects included & \multicolumn{8}{|c|}{ Year, Country, Industry } \\
\hline Number of countries & 41 & 41 & 32 & 26 & 33 & 26 & 11 & 8 \\
\hline Number of observations & 196,016 & 196,016 & 181,122 & 165,467 & 187,146 & 163,416 & 57,514 & 50,515 \\
\hline Adjusted $R^{2}$ & 0.218 & 0.218 & 0.219 & 0.225 & 0.220 & 0.226 & 0.210 & 0.203 \\
\hline
\end{tabular}

Panel B: The Effect of Board-related Components versus Additional Non-board Components

\begin{tabular}{|c|c|c|c|c|}
\hline \multirow[b]{2}{*}{ Variables } & \multicolumn{2}{|c|}{ Major reform } & \multicolumn{2}{|c|}{ First reform } \\
\hline & (1) & (2) & (3) & (4) \\
\hline \multirow{2}{*}{ Post (reforms with at least two board-related component) } & $0.204 * *$ & $0.172 * *$ & $0.317 * * *$ & $0.227 * * *$ \\
\hline & $(2.47)$ & $(2.13)$ & $(4.03)$ & $(2.71)$ \\
\hline \multirow{2}{*}{ Post (reforms with one board-related components } & $0.109 * *$ & 0.088 & 0.019 & -0.043 \\
\hline & $(2.12)$ & $(1.59)$ & $(0.30)$ & $(-0.66)$ \\
\hline \multirow[t]{2}{*}{ Post (reforms with additional non-board component) } & & 0.080 & & $0.151 * *$ \\
\hline & & $(1.52)$ & & $(2.43)$ \\
\hline Controls & Yes & Yes & Yes & Yes \\
\hline Fixed effects included & \multicolumn{4}{|c|}{ Year, Country, Industry } \\
\hline Number of countries & 41 & 41 & 41 & 41 \\
\hline Number of observations & 196,016 & 196,016 & 196,016 & 196,016 \\
\hline Adjusted $R^{2}$ & 0.218 & 0.218 & 0.218 & 0.219 \\
\hline
\end{tabular}




\section{TABLE 7}

\section{Board Reforms and Ex Ante Institutional Quality}

This table presents the analysis of the impact of board reforms on Tobin's q, conditional on ex ante institutional quality. $t$-statistics, in parentheses, are based on standard errors clustered at the country level. $*, * *$, and $* * *$ indicate significance at the $10 \%, 5 \%$, and $1 \%$ two-tailed level, respectively. See Appendix B for variable definitions.

\begin{tabular}{|c|c|c|c|c|c|c|}
\hline \multirow[b]{2}{*}{ Variables } & \multicolumn{3}{|c|}{ Major reform } & \multicolumn{3}{|c|}{ First reform } \\
\hline & (1) & $(2)$ & (3) & (4) & (5) & (6) \\
\hline Post & $\begin{array}{l}0.019 \\
(0.56)\end{array}$ & $\begin{array}{l}-0.064 \\
(-1.63)\end{array}$ & $\begin{array}{l}-0.005 \\
(-0.12)\end{array}$ & $\begin{array}{l}0.017 \\
(\mathbf{0 . 5 9 )}\end{array}$ & $\begin{array}{l}-0.054 \\
(-1.65)\end{array}$ & $\begin{array}{l}-0.007 \\
(-0.23)\end{array}$ \\
\hline $\begin{array}{l}\text { Post } \times \text { Low Rule of } \\
\text { Law }\end{array}$ & $\begin{array}{l}0.100 * * \\
(2.55)\end{array}$ & & & $\begin{array}{l}\text { 0.110** } \\
(2.69)\end{array}$ & & \\
\hline Post $\times$ Low Disclosure & & $\begin{array}{l}0.205 * * * \\
(4.39)\end{array}$ & & & $\begin{array}{l}0.220 * * * \\
(4.26)\end{array}$ & \\
\hline Post $\times$ Code Law & & & $\begin{array}{l}\text { 0.175*** } \\
(\mathbf{3 . 5 1})\end{array}$ & & & $\begin{array}{l}0.180 * * * \\
(2.94)\end{array}$ \\
\hline Low Rule of Law & $\begin{array}{l}-0.025 \\
(-0.99)\end{array}$ & & & $\begin{array}{l}-0.029 \\
(-1.04)\end{array}$ & & \\
\hline Size & $\begin{array}{l}-0.060 * * * \\
(-5.02)\end{array}$ & $\begin{array}{l}-0.055^{* * * *} \\
(-4.70)\end{array}$ & $\begin{array}{l}-0.059 * * * \\
(-4.99)\end{array}$ & $\begin{array}{l}-0.060 * * * \\
(-5.02)\end{array}$ & $\begin{array}{l}-0.055 * * * \\
(-4.70)\end{array}$ & $\begin{array}{l}-0.059 * * * \\
(-5.00)\end{array}$ \\
\hline Age & $\begin{array}{l}-0.053 * * * \\
(-2.83)\end{array}$ & $\begin{array}{l}-0.062 * * * \\
(-3.52)\end{array}$ & $\begin{array}{l}-0.055^{* * *} \\
(-2.95)\end{array}$ & $\begin{array}{l}-0.053 * * * \\
(-2.86)\end{array}$ & $\begin{array}{l}-0.063 * * * \\
(-3.49)\end{array}$ & $\begin{array}{l}-0.055 * * * \\
(-2.94)\end{array}$ \\
\hline Leverage & $\begin{array}{l}-0.693 * * * \\
(-3.38)\end{array}$ & $\begin{array}{l}-0.689 * * * \\
(-3.34)\end{array}$ & $\begin{array}{l}-0.690 * * * \\
(-3.39)\end{array}$ & $\begin{array}{l}-0.693 * * * \\
(-3.38)\end{array}$ & $\begin{array}{l}-0.687 * * * \\
(-3.32)\end{array}$ & $\begin{array}{l}-0.690 * * * \\
(-3.40)\end{array}$ \\
\hline Cash & $\begin{array}{l}1.791 * * * \\
(15.64)\end{array}$ & $\begin{array}{l}1.824 * * * \\
(16.19)\end{array}$ & $\begin{array}{l}1.802 * * * \\
(15.80)\end{array}$ & $\begin{array}{l}1.790^{* * * *} \\
(15.65)\end{array}$ & $\begin{array}{l}1.828 * * * \\
(16.37)\end{array}$ & $\begin{array}{l}1.803 * * * \\
(15.79)\end{array}$ \\
\hline$P P E$ & $\begin{array}{l}-0.022 * * \\
(-2.46)\end{array}$ & $\begin{array}{l}-0.024 * * \\
(-2.72)\end{array}$ & $\begin{array}{l}-0.022 * * \\
(-2.48)\end{array}$ & $\begin{array}{l}-0.022 * * \\
(-2.47)\end{array}$ & $\begin{array}{l}-0.024 * * * \\
(-2.73)\end{array}$ & $\begin{array}{l}-0.022 * * \\
(-2.47)\end{array}$ \\
\hline Foreign Sales & $\begin{array}{c}0.045 \\
(1.47)\end{array}$ & $\begin{array}{c}0.040 \\
(1.31)\end{array}$ & $\begin{array}{r}0.045 \\
(1.44)\end{array}$ & $\begin{array}{c}0.045 \\
(1.49)\end{array}$ & $\begin{array}{c}0.039 \\
(1.27)\end{array}$ & $\begin{array}{c}0.044 \\
(1.42)\end{array}$ \\
\hline$R \& D$ & $\begin{array}{l}0.857 * * * \\
(11.46)\end{array}$ & $\begin{array}{l}0.855^{* * *} \\
(11.55)\end{array}$ & $\begin{array}{l}0.856^{* * * *} \\
(11.30)\end{array}$ & $\begin{array}{l}0.858^{* * * *} \\
(11.35)\end{array}$ & $\begin{array}{l}0.859 * * * \\
(11.33)\end{array}$ & $\begin{array}{l}0.857 * * * \\
(11.22)\end{array}$ \\
\hline Capex & $\begin{array}{l}1.721 * * * \\
(4.44)\end{array}$ & $\begin{array}{l}1.741 * * * \\
(4.53)\end{array}$ & $\begin{array}{l}1.720^{* * *} \\
(4.50)\end{array}$ & $\begin{array}{l}1.721^{* * * *} \\
(4.44)\end{array}$ & $\begin{array}{l}1.737 * * * \\
(4.51)\end{array}$ & $\begin{array}{l}1.717 * * * \\
(4.50)\end{array}$ \\
\hline Closely Held & $\begin{array}{l}-0.071 \\
(-0.67)\end{array}$ & $\begin{array}{l}-0.060 \\
(-0.54)\end{array}$ & $\begin{array}{c}-0.064 \\
(-0.59)\end{array}$ & $\begin{array}{l}-0.069 \\
(-0.65)\end{array}$ & $\begin{array}{c}-0.063 \\
(-0.56)\end{array}$ & $\begin{array}{l}-0.064 \\
(-0.59)\end{array}$ \\
\hline$A D R$ & $\begin{array}{l}0.268 * * * \\
(7.76)\end{array}$ & $\begin{array}{l}0.274 * * * \\
(8.31)\end{array}$ & $\begin{array}{l}0.263 * * * \\
(7.99)\end{array}$ & $\begin{array}{l}0.268 * * * \\
(7.77)\end{array}$ & $\begin{array}{l}0.275^{* * *} \\
(8.28)\end{array}$ & $\begin{array}{l}0.263 * * * \\
(8.02)\end{array}$ \\
\hline $\log G D P$ & $\begin{array}{l}0.130^{* * *} \\
(2.21)\end{array}$ & $\begin{array}{c}0.083 \\
(1.51)\end{array}$ & $\begin{array}{l}0.143 * * * \\
(2.92)\end{array}$ & $\begin{array}{l}0.154 * * * \\
(2.71)\end{array}$ & $\begin{array}{l}0.131 * * \\
(2.35)\end{array}$ & $\begin{array}{l}0.160 \text { *** } \\
(2.96)\end{array}$ \\
\hline$F D I$ & $\begin{array}{r}0.147 \\
(0.62)\end{array}$ & $\begin{array}{c}0.409 \\
(1.50)\end{array}$ & $\begin{array}{c}0.391 \\
(1.58)\end{array}$ & $\begin{array}{c}0.146 \\
(0.62)\end{array}$ & $\begin{array}{l}0.437^{*} \\
(1.76)\end{array}$ & $\begin{array}{c}0.361 \\
(1.47)\end{array}$ \\
\hline Industry $q$ & $\begin{array}{l}0.877 * * * \\
(9.72)\end{array}$ & $\begin{array}{l}0.871 * * * \\
(10.07)\end{array}$ & $\begin{array}{l}0.879 * * * \\
(10.41)\end{array}$ & $\begin{array}{l}0.877 * * * \\
(9.80)\end{array}$ & $\begin{array}{l}0.864 * * * \\
(10.05)\end{array}$ & $\begin{array}{l}0.877^{* * *} \\
(10.58)\end{array}$ \\
\hline Fixed effects included & & & Year, $\mathrm{Co}$ & Industry & & \\
\hline Number of observations & 196,016 & 191,636 & 196,016 & 196,016 & 191,636 & 196,016 \\
\hline Adjusted $R^{2}$ & 0.236 & 0.235 & 0.236 & 0.236 & 0.235 & 0.236 \\
\hline
\end{tabular}


TABLE 8

Board Reforms and Firm-level Characteristics

This table presents the analysis of the impact of board reforms on Tobin's q, conditional on ex ante firm-level governance and information environments. $t$-statistics, in parentheses, are based on standard errors clustered at the country level. *, **, and $* * *$ indicate significance at the $10 \%, 5 \%$, and $1 \%$ two-tailed level, respectively. See Appendix B for variable definitions.

\begin{tabular}{|c|c|c|c|c|c|c|}
\hline \multirow[b]{2}{*}{ Variables } & \multicolumn{3}{|c|}{ Major reform } & \multicolumn{3}{|c|}{ First reform } \\
\hline & (1) & (2) & (3) & (4) & (5) & (6) \\
\hline \multirow[t]{2}{*}{ Post } & -0.066 & $-0.100 *$ & -0.091 & -0.129 & -0.080 & -0.100 \\
\hline & $(-1.42)$ & $(-1.93)$ & $(-1.26)$ & $(-1.39)$ & $(-1.11)$ & $(-1.17)$ \\
\hline \multirow[t]{2}{*}{ Post $\times$ Low Governance } & $0.234 * *$ & & & $0.256 * *$ & & \\
\hline & $(2.27)$ & & & $(2.18)$ & & \\
\hline Low Governance & $\begin{array}{l}-0.339 * * \\
(-2.60)\end{array}$ & & & $\begin{array}{l}-0.366^{* *} \\
(-2.53)\end{array}$ & & \\
\hline Post $\times$ Low Coverage & & $\begin{array}{l}0.276^{* * *} \\
(2.56)\end{array}$ & & & $\begin{array}{l}0.270^{* *} \\
(2.12)\end{array}$ & \\
\hline Low Coverage & & $\begin{array}{l}-0.435 * * * \\
(-4.30)\end{array}$ & & & $\begin{array}{l}-0.452 * * * \\
(-3.94)\end{array}$ & \\
\hline Post $\times$ High Dispersion & & & $\begin{array}{l}0.231 * * \\
(2.46)\end{array}$ & & & $\begin{array}{l}0.276 \text { **** } \\
(2.84)\end{array}$ \\
\hline High Dispersion & & & $\begin{array}{l}-0.449 * * * \\
(-3.08)\end{array}$ & & & $\begin{array}{l}-0.492 * * * \\
(-3.34)\end{array}$ \\
\hline Size & $\begin{array}{l}-0.088^{* * *} \\
(-5.13)\end{array}$ & $\begin{array}{l}-0.056^{* * *} \\
(-6.38)\end{array}$ & $\begin{array}{l}-0.009 \\
(-0.89)\end{array}$ & $\begin{array}{l}-0.088^{* * *} \\
(-5.20)\end{array}$ & $\begin{array}{l}-0.055^{* * *} \\
(-6.36)\end{array}$ & $\begin{array}{c}-0.010 \\
(-0.92)\end{array}$ \\
\hline Age & $\begin{array}{l}-0.103^{* * *} \\
(-3.58)\end{array}$ & $\begin{array}{l}-0.058 * * * \\
(-3.27)\end{array}$ & $\begin{array}{l}-0.064^{* * *} \\
(-3.95)\end{array}$ & $\begin{array}{l}-0.103^{* * *} \\
(-3.59)\end{array}$ & $\begin{array}{l}-0.058^{* * *} \\
(-3.27)\end{array}$ & $\begin{array}{l}-0.065^{* * *} \\
(-4.02)\end{array}$ \\
\hline Leverage & $\begin{array}{l}-1.123^{* * *} \\
(-3.04)\end{array}$ & $\begin{array}{l}-0.772 * * * \\
(-2.73)\end{array}$ & $\begin{array}{l}-1.037 * * * \\
(-3.44)\end{array}$ & $\begin{array}{l}-1.122 * * * \\
(-3.05)\end{array}$ & $\begin{array}{l}-0.775 \text { *** } \\
(-2.73)\end{array}$ & $\begin{array}{l}-1.030 * * * \\
(-3.43)\end{array}$ \\
\hline Cash & $\begin{array}{l}1.735^{* * * *} \\
(19.83)\end{array}$ & $\begin{array}{l}1.435^{* * * *} \\
(12.78)\end{array}$ & $\begin{array}{l}1.712^{* * * *} \\
(19.89)\end{array}$ & $\begin{array}{l}1.736^{* * * *} \\
(19.86)\end{array}$ & $\begin{array}{l}1.438 * * * \\
(12.76)\end{array}$ & $\begin{array}{l}1.714^{* * *} \\
(19.99)\end{array}$ \\
\hline$P P E$ & $\begin{array}{l}-0.031 * \\
(-1.89)\end{array}$ & $\begin{array}{l}-0.036^{* * * *} \\
(-3.54)\end{array}$ & $\begin{array}{l}-0.060 * * * \\
(-4.96)\end{array}$ & $\begin{array}{l}-0.031^{*} \\
(-1.90)\end{array}$ & $\begin{array}{l}-0.036 * * * \\
(-3.54)\end{array}$ & $\begin{array}{l}-0.059 * * * \\
(-4.99)\end{array}$ \\
\hline Foreign Sales & $\begin{array}{c}-0.030 \\
(-0.50)\end{array}$ & $\begin{array}{c}0.015 \\
(0.35)\end{array}$ & $\begin{array}{r}0.017 \\
(0.44)\end{array}$ & $\begin{array}{r}-0.031 \\
(-0.53)\end{array}$ & $\begin{array}{r}0.017 \\
(0.38)\end{array}$ & $\begin{array}{c}0.016 \\
(0.44)\end{array}$ \\
\hline$R \& D$ & $\begin{array}{l}0.650^{* * * *} \\
(8.51)\end{array}$ & $\begin{array}{l}0.887^{* * * *} \\
(7.34)\end{array}$ & $\begin{array}{l}0.681^{* * * *} \\
(6.79)\end{array}$ & $\begin{array}{l}0.649 * * * \\
(8.27)\end{array}$ & $\begin{array}{l}0.890 * * * \\
(7.32)\end{array}$ & $\begin{array}{l}0.683^{* * *} \\
(6.68)\end{array}$ \\
\hline Capex & $\begin{array}{l}2.873^{* * * *} \\
(5.82)\end{array}$ & $\begin{array}{l}1.964 \text { *** } \\
(4.75)\end{array}$ & $\begin{array}{l}1.936^{* * *} \\
(5.58)\end{array}$ & $\begin{array}{l}2.871 \text { *** } \\
(5.87)\end{array}$ & $\begin{array}{l}1.966^{* * * *} \\
(4.78)\end{array}$ & $\begin{array}{l}1.937 * * * * \\
(5.58)\end{array}$ \\
\hline Closely Held & $\begin{array}{c}-0.232 \\
(-1.40)\end{array}$ & $\begin{array}{c}-0.046 \\
(-0.48)\end{array}$ & $\begin{array}{c}-0.074 \\
(-0.66)\end{array}$ & $\begin{array}{l}-0.237 \\
(-1.43)\end{array}$ & $\begin{array}{l}-0.051 \\
(-0.52)\end{array}$ & $\begin{array}{l}-0.075 \\
(-0.66)\end{array}$ \\
\hline$A D R$ & $\begin{array}{l}0.207 * * * \\
(6.99)\end{array}$ & $\begin{array}{l}0.202^{* * *} \\
(6.15)\end{array}$ & $\begin{array}{l}0.193 * * * \\
(7.31)\end{array}$ & $\begin{array}{l}0.209^{* * * *} \\
(6.90)\end{array}$ & $\begin{array}{l}0.201 * * * \\
(5.93)\end{array}$ & $\begin{array}{l}0.192 * * * \\
(7.34)\end{array}$ \\
\hline \multicolumn{7}{|l|}{ Country-level variables } \\
\hline $\log G D P$ & $\begin{array}{r}-0.140 \\
(-1.03)\end{array}$ & $\begin{array}{c}0.120 \\
(1.45)\end{array}$ & $\begin{array}{c}0.143 \\
(1.50)\end{array}$ & $\begin{array}{c}-0.144 \\
(-0.99)\end{array}$ & $\begin{array}{l}0.141^{*} \\
(1.72)\end{array}$ & $\begin{array}{l}0.186^{* * *} \\
(2.27)\end{array}$ \\
\hline$F D I$ & $\begin{array}{c}0.975 \\
(1.22)\end{array}$ & $\begin{array}{c}0.372 \\
(1.36)\end{array}$ & $\begin{array}{c}0.340 \\
(0.84)\end{array}$ & $\begin{array}{r}1.001 \\
(1.24)\end{array}$ & $\begin{array}{c}0.376 \\
(1.32)\end{array}$ & $\begin{array}{c}0.421 \\
(1.05)\end{array}$ \\
\hline \multicolumn{7}{|l|}{ Time trend variables } \\
\hline Industry $q$ & $\begin{array}{l}0.725^{* * * *} \\
(5.43)\end{array}$ & $\begin{array}{l}0.799 * * * \\
(9.16)\end{array}$ & $\begin{array}{l}0.819^{* * * *} \\
(9.29)\end{array}$ & $\begin{array}{l}0.726^{* * *} \\
(5.62)\end{array}$ & $\begin{array}{l}0.797 * * * \\
(9.21)\end{array}$ & $\begin{array}{l}0.816^{* * *} \\
(9.47)\end{array}$ \\
\hline Fixed effects included & & & Year, Coul & , Industry & & \\
\hline Number of observations & 38,766 & 131,088 & 116,995 & 38,766 & 131,088 & 116,995 \\
\hline Adjusted $R^{2}$ & 0.262 & 0.262 & 0.271 & 0.262 & 0.262 & 0.271 \\
\hline
\end{tabular}




\section{TABLE 9}

The Effect of Comply-or-explain Reforms versus Regulation Reforms

Panels A and B present the analysis of the impact of board reforms on Tobin's $q$ for comply-or-explain and regulation reforms, respectively. $t$-statistics, in parentheses, are based on standard errors clustered at the country level. *,**, and $* * *$ indicate significance at the $10 \%, 5 \%$, and $1 \%$ two-tailed level, respectively. See Appendix B for variable definitions.

Panel A: Comply-or-explain Reform

\begin{tabular}{lcccc}
\hline & \multicolumn{2}{c}{$\begin{array}{c}\text { Major reform } \\
\mathbf{( 2 2} \text { countries })\end{array}$} & \multicolumn{2}{c}{$\begin{array}{c}\text { First reform } \\
\mathbf{2 5} \text { countries })\end{array}$} \\
\cline { 2 - 5 } Variables & $\mathbf{( 1 )}$ & $\mathbf{( 2 )}$ & $\mathbf{( 3 )}$ & $\mathbf{( 4 )}$ \\
\hline Post $\left(\beta_{1}\right)$ & $0.097 * *$ & $0.072^{*}$ & $0.111^{* * *}$ & $0.083^{* * *}$ \\
& $(2.13)$ & $(1.79)$ & $(4.48)$ & $(3.13)$ \\
Post x Low Rule of Law $\left(\beta_{2}\right)$ & & 0.083 & & 0.075 \\
& & $(1.40)$ & Yes & $(1.67)$ \\
Controls & Yes & Yes & Year, Country, Industry & \\
Fixed effects included & \multicolumn{4}{c}{ Yes } \\
Number of observations & 85,964 & 85,964 & 94,145 & 94,145 \\
Adjusted $R^{2}$ & 0.220 & 0.220 & 0.222 & 0.222 \\
\hline
\end{tabular}

Panel B: Regulation Reform

\begin{tabular}{|c|c|c|c|c|}
\hline \multirow[b]{2}{*}{ Variables } & \multicolumn{2}{|c|}{$\begin{array}{l}\text { Major reform } \\
(19 \text { countries) }\end{array}$} & \multicolumn{2}{|c|}{$\begin{array}{l}\text { First reform } \\
\text { (16 countries) }\end{array}$} \\
\hline & (1) & $(2)$ & (3) & (4) \\
\hline $\operatorname{Post}\left(\beta_{1}\right)$ & 0.060 & -0.120 & 0.050 & -0.081 \\
\hline & $(0.97)$ & $(-1.55)$ & $(0.88)$ & $(-1.14)$ \\
\hline Post $x$ Low Rule of Law $\left(\beta_{2}\right)$ & & $\begin{array}{l}0.257 * * * \\
(6.77)\end{array}$ & & $\begin{array}{l}0.214 * * * \\
(4.69)\end{array}$ \\
\hline Controls & Yes & Yes & Yes & Yes \\
\hline Fixed effects included & \multicolumn{4}{|c|}{ Year, Country, Industry } \\
\hline Number of observations & 110,052 & 110,052 & 101,871 & 101,871 \\
\hline Adjusted $R^{2}$ & 0.248 & 0.249 & 0.250 & 0.251 \\
\hline
\end{tabular}




\section{TABLE 10}

The Impact of Board Reforms on Firm Performance and Investment-Cash Flow Sensitivity This table presents the analysis of the impact of board reforms on firm profitability, reporting quality, and investment- cash flow sensitivity. Dependent variables are return on assets $(R O A)$, return on equity $(R O E)$, absolute discretionary accruals $(|D A C C|)$, Investment, and Asset Growth. $t$-statistics, in parentheses, are based on standard errors clustered at the country level. *, **, and *** indicate significance at the $10 \%, 5 \%$, and $1 \%$ two-tailed level, respectively. See Appendix B for variable definitions.

Panel A: The Effect of Board Reforms on Firm Profitability and Reporting Quality

\begin{tabular}{|c|c|c|c|c|c|c|}
\hline \multirow[b]{3}{*}{ Variables } & \multicolumn{3}{|c|}{ Major reform } & \multicolumn{2}{|c|}{ First reform } & \multirow[b]{2}{*}{$|\mathbf{D A C C}|$} \\
\hline & ROA & ROE & $|\mathbf{D A C C}|$ & ROA & ROE & \\
\hline & (1) & (2) & (3) & (4) & (5) & (6) \\
\hline \multirow[t]{2}{*}{ Post } & $0.008 * *$ & $0.012 *$ & $-0.825^{* *}$ & $0.012 * * *$ & $0.021 * *$ & -0.003 \\
\hline & $(2.08)$ & $(1.71)$ & $(-2.11)$ & $(4.41)$ & $(2.63)$ & $(-0.01)$ \\
\hline \multirow[t]{2}{*}{ Size } & $0.018^{* * *}$ & $0.047 * * *$ & $-0.037 * *$ & $0.018 * * *$ & $0.047 * * *$ & $-0.039 * *$ \\
\hline & $(7.55)$ & $(9.50)$ & $(-2.05)$ & $(7.54)$ & $(9.49)$ & $(-2.12)$ \\
\hline \multirow[t]{2}{*}{ Age } & 0.001 & 0.000 & 0.025 & 0.000 & 0.000 & 0.019 \\
\hline & $(0.23)$ & $(0.09)$ & $(1.28)$ & $(0.19)$ & $(0.05)$ & $(1.34)$ \\
\hline \multirow[t]{2}{*}{ Leverage } & $-0.099 * * *$ & $-0.365^{* * *}$ & -0.061 & $-0.099 * * *$ & $-0.365^{* * *}$ & -0.059 \\
\hline & $(-18.70)$ & $(-16.42)$ & $(-0.83)$ & $(-19.06)$ & $(-16.52)$ & $(-0.79)$ \\
\hline \multirow[t]{2}{*}{ Cash } & -0.004 & -0.017 & -0.002 & -0.004 & -0.018 & -0.025 \\
\hline & $(-0.31)$ & $(-0.86)$ & $(-0.03)$ & $(-0.33)$ & $(-0.88)$ & $(-0.30)$ \\
\hline \multirow[t]{2}{*}{$P P E$} & $-0.011 * * *$ & $-0.021 * * *$ & -0.003 & $-0.011 * * *$ & $-0.021 * * *$ & -0.006 \\
\hline & $(-10.68)$ & $(-10.40)$ & $(-0.32)$ & $(-10.73)$ & $(-10.48)$ & $(-0.60)$ \\
\hline Foreign Sales & $\begin{array}{l}-0.011 * * * \\
(-4.44)\end{array}$ & $\begin{array}{l}-0.029 * * * \\
(-5.96)\end{array}$ & $\begin{array}{r}0.027 \\
(0.34)\end{array}$ & $\begin{array}{c}-0.011 * * * \\
(-4.40)\end{array}$ & $\begin{array}{l}-0.029 * * * \\
(-5.92)\end{array}$ & $\begin{array}{c}0.038 \\
(0.52)\end{array}$ \\
\hline$R \& D$ & $\begin{array}{l}-0.171 * * * \\
(-30.67)\end{array}$ & $\begin{array}{c}-0.323^{* * *} \\
(-34.22)\end{array}$ & $\begin{array}{c}0.054 \\
(1.01)\end{array}$ & $\begin{array}{l}-0.171 * * * \\
(-30.86)\end{array}$ & $\begin{array}{c}-0.323^{* * * *} \\
(-33.93)\end{array}$ & $\begin{array}{c}0.068 \\
(1.25)\end{array}$ \\
\hline Capex & $\begin{array}{l}0.122^{* * * *} \\
(22.12)\end{array}$ & $\begin{array}{c}0.301 * * * \\
(12.63)\end{array}$ & $\begin{array}{c}1.818 \\
(1.56)\end{array}$ & $\begin{array}{l}0.122 * * * \\
(22.68)\end{array}$ & $\begin{array}{l}0.301^{\text {*** }} \\
(12.76)\end{array}$ & $\begin{array}{c}1.789 \\
(1.53)\end{array}$ \\
\hline Closely Held & $\begin{array}{l}0.020^{* * *} \\
(4.05)\end{array}$ & $\begin{array}{l}0.038^{* * * *} \\
(3.89)\end{array}$ & $\begin{array}{c}0.015 \\
(0.22)\end{array}$ & $\begin{array}{c}0.020 * * * \\
(4.12)\end{array}$ & $\begin{array}{l}0.038^{* * *} \\
(3.95)\end{array}$ & $\begin{array}{c}0.022 \\
(0.34)\end{array}$ \\
\hline$A D R$ & $\begin{array}{l}-0.015^{* * * *} \\
(-3.29)\end{array}$ & $\begin{array}{l}-0.035^{* * * *} \\
(-3.75)\end{array}$ & $\begin{array}{l}-0.040 \\
(-0.86)\end{array}$ & $\begin{array}{c}-0.015^{* * *} \\
(-3.28)\end{array}$ & $\begin{array}{l}-0.035^{* * * *} \\
(-3.75)\end{array}$ & $\begin{array}{c}-0.037 \\
(-0.78)\end{array}$ \\
\hline \multicolumn{7}{|l|}{ Country-level variables } \\
\hline $\log G D P$ & $\begin{array}{l}-0.038 * * * \\
(-5.88)\end{array}$ & $\begin{array}{l}-0.059 * * * \\
(-4.64)\end{array}$ & $\begin{array}{c}1.594 \\
(1.54)\end{array}$ & $\begin{array}{c}-0.034 * * * \\
(-5.65)\end{array}$ & $\begin{array}{l}-0.052 \text { *** } \\
(-4.18)\end{array}$ & $\begin{array}{l}1.716^{*} \\
(1.76)\end{array}$ \\
\hline$F D I$ & $\begin{array}{c}0.014 \\
(0.46)\end{array}$ & $\begin{array}{c}0.065 \\
(1.08)\end{array}$ & $\begin{array}{c}1.585 \\
(0.42)\end{array}$ & $\begin{array}{c}0.013 \\
(0.39)\end{array}$ & $\begin{array}{c}0.061 \\
(0.92)\end{array}$ & $\begin{array}{r}0.001 \\
(0.00)\end{array}$ \\
\hline \multicolumn{7}{|l|}{ Time trend variables } \\
\hline Industry ROA & $\begin{array}{l}0.687 * * * \\
(6.08)\end{array}$ & & & $\begin{array}{c}0.688^{* * * *} \\
(6.15)\end{array}$ & & \\
\hline Industry ROE & & $\begin{array}{l}1.002^{* * * *} \\
(9.39)\end{array}$ & & & $\begin{array}{l}1.002 \text { *** } \\
(9.42)\end{array}$ & \\
\hline Fixed effects included & \multicolumn{6}{|c|}{ Year, Country, Industry } \\
\hline Number of observations & 195,660 & 195,660 & 89,162 & 195,660 & 195,660 & 89,162 \\
\hline Adjusted $R^{2}$ & 0.321 & 0.280 & 0.0260 & 0.321 & 0.280 & 0.0255 \\
\hline
\end{tabular}


TABLE 10, CONTINUED

Panel B: The Effect of Board Reform and Investment-Cash Flow Sensitivity

\begin{tabular}{|c|c|c|c|c|}
\hline \multirow[b]{3}{*}{ Variables } & \multicolumn{2}{|c|}{ Major reform } & \multicolumn{2}{|c|}{ First reform } \\
\hline & INV & Asset Growth & INV & Asset Growth \\
\hline & (1) & $(2)$ & (3) & (4) \\
\hline \multirow[t]{2}{*}{ Post } & 0.003 & 0.025 & 0.003 & $0.036 * *$ \\
\hline & $(0.76)$ & $(1.38)$ & $(0.67)$ & $(2.52)$ \\
\hline \multirow[t]{2}{*}{ Post $\times$ Cash Flow ${ }_{t-1}$} & $-0.022 * * *$ & $-0.072 * * *$ & $-0.021 * * *$ & $-0.078 * * *$ \\
\hline & $(-3.88)$ & $(-4.37)$ & $(-4.04)$ & $(-4.82)$ \\
\hline \multirow[t]{2}{*}{$q_{t-1}$} & $0.011 * *$ & -0.010 & $0.011 * *$ & -0.011 \\
\hline & $(2.06)$ & $(-0.55)$ & $(2.10)$ & $(-0.61)$ \\
\hline \multirow[t]{2}{*}{ Cash Flow $_{t-1}$} & $0.024 * * *$ & $0.070 * * *$ & $0.023 * * *$ & $0.076^{* * *}$ \\
\hline & $(3.73)$ & $(4.67)$ & $(3.77)$ & $(5.04)$ \\
\hline \multirow[t]{2}{*}{$q_{t-1} \times G D P$} & -0.000 & $0.007 * * *$ & -0.000 & $0.007 * * *$ \\
\hline & $(-0.50)$ & $(3.47)$ & $(-0.52)$ & $(3.51)$ \\
\hline \multirow[t]{2}{*}{ Cash Flow $_{t-1} \times G D P$} & $-0.000 * * *$ & $0.000 * *$ & $-0.000 * * *$ & $0.000 * *$ \\
\hline & $(-3.06)$ & $(2.12)$ & $(-3.23)$ & $(2.12)$ \\
\hline Fixed effects included & \multicolumn{4}{|c|}{ Year, Country, Industry } \\
\hline Number of observations & 174,808 & 174,808 & 174,808 & 174,808 \\
\hline Adjusted $R^{2}$ & 0.168 & 0.130 & 0.168 & 0.131 \\
\hline
\end{tabular}




\section{TABLE 11}

\section{Sensitivity Tests}

This table presents the robustness checks of the impact of board reforms on firm value. The dependent variable is Tobin's $q$, unless otherwise noted. $t$-statistics, in parentheses, are based on standard errors clustered at the country level. *,**, and *** indicate significance at the $10 \%, 5 \%$, and $1 \%$ two-tailed level, respectively. See Appendix B for variable definitions.

\section{Panel A: Major Reform}

\begin{tabular}{|c|c|c|c|c|}
\hline \multirow[b]{2}{*}{ Variables } & \multicolumn{2}{|c|}{ Excluding the U.S. } & \multicolumn{2}{|c|}{$\begin{array}{c}\text { Dependent variable = } \\
\text { Market-to-Book }\end{array}$} \\
\hline & (1) & (2) & (3) & (4) \\
\hline Post $\left(\beta_{1}\right)$ & $0.052 * *$ & 0.021 & $0.175^{*}$ & -0.003 \\
\hline & $(2.30)$ & $(0.99)$ & $(1.75)$ & $(-0.04)$ \\
\hline Post $\times$ Low Rule of Law $\left(\beta_{2}\right)$ & & $\begin{array}{l}0.066^{*} \\
(1.97)\end{array}$ & & $\begin{array}{l}0.356^{* * *} \\
(3.43)\end{array}$ \\
\hline Controls & Yes & Yes & Yes & Yes \\
\hline Fixed effects included & & Year, C & ountry, Indus & \\
\hline Number of observations & 154,728 & 154,728 & 196,003 & 196,003 \\
\hline Adjusted $R^{2}$ & 0.235 & 0.235 & 0.147 & 0.147 \\
\hline
\end{tabular}

\section{Panel B: First Reform}

\begin{tabular}{|c|c|c|c|c|}
\hline \multirow[b]{2}{*}{ Variables } & \multicolumn{2}{|c|}{ Excluding the U.S. } & \multicolumn{2}{|c|}{$\begin{array}{c}\text { Dependent variable = } \\
\text { Market-to-Book }\end{array}$} \\
\hline & (1) & (2) & (3) & (4) \\
\hline $\operatorname{Post}\left(\beta_{1}\right)$ & $\begin{array}{l}0.088 * * * \\
(2.93)\end{array}$ & $\begin{array}{l}0.055^{*} \\
(1.82)\end{array}$ & $\begin{array}{l}0.332 * * \\
(2.45)\end{array}$ & $\begin{array}{l}0.192 \\
(1.36)\end{array}$ \\
\hline Post $\times$ Low Rule of Law $\left(\beta_{2}\right)$ & & $\begin{array}{l}0.062 * * \\
(2.27)\end{array}$ & & $\begin{array}{l}0.283^{* * *} \\
(3.42)\end{array}$ \\
\hline $\begin{array}{l}\text { Controls } \\
\text { Fixed effects included }\end{array}$ & Yes & $\begin{array}{l}\text { Yes } \\
\text { Year, }\end{array}$ & $\begin{array}{l}\text { Yes } \\
\text { ry, Industry }\end{array}$ & Yes \\
\hline $\begin{array}{l}\text { Number of observations } \\
\text { Adjusted } \mathrm{R}^{2}\end{array}$ & $\begin{array}{c}154,728 \\
0.235 \\
\end{array}$ & $\begin{array}{c}154,728 \\
0.235 \\
\end{array}$ & $\begin{array}{c}196,003 \\
0.147 \\
\end{array}$ & $\begin{array}{c}196,003 \\
0.148 \\
\end{array}$ \\
\hline
\end{tabular}




\section{APPENDIX A \\ Description of Corporate Board Reforms Worldwide}

\section{Data are from the World Bank Group Reports on the Observance of Standards and Codes' (ROSC)}

Corporate Governance Assessment, European Corporate Governance Institute (ECGI), and Kim and Lu

\begin{tabular}{|c|c|c|c|}
\hline Country & Reform & Year & Description \\
\hline Argentina & $\begin{array}{l}\text { Major reform, } \\
\text { first reform }\end{array}$ & 2001 & $\begin{array}{l}\text { Capital Markets Law, which incorporates corporate governance principles from } \\
\text { the Organisation for Economic Co-operation and Development (OECD), } \\
\text { became effective. }\end{array}$ \\
\hline \multirow[t]{2}{*}{ Australia } & Major reform & 2004 & $\begin{array}{l}\text { Audit Reform and Corporate Disclosure Act of } 2004 \text { (also known as CLERP 9) } \\
\text { and the Australian Stock Exchange's Principles of Good Corporate Governance } \\
\text { for Listed Companies became effective. }\end{array}$ \\
\hline & First reform & 2003 & Corporate Governance Principles and Recommendations became effective. \\
\hline \multirow[t]{2}{*}{ Austria } & Major reform & 2004 & $\begin{array}{l}\text { The Vienna Stock Exchange began enforcing the Austrian Code of Corporate } \\
\text { Governance. }\end{array}$ \\
\hline & First reform & 2002 & The code became effective. \\
\hline \multirow[t]{2}{*}{ Belgium } & Major reform & 2005 & The new Belgian Code of Corporate Governance became effective. \\
\hline & First reform & 1998 & $\begin{array}{l}\text { Obligation for disclosure on the basis of the comply-or-explain model became } \\
\text { effective in the listing requirements of the Brussels Stock Exchange. }\end{array}$ \\
\hline Brazil & $\begin{array}{l}\text { Major reform, } \\
\text { first reform }\end{array}$ & 2002 & The New Corporation Law became effective. \\
\hline Canada & $\begin{array}{l}\text { Major reform, } \\
\text { first reform }\end{array}$ & 2004 & $\begin{array}{l}\text { Various reforms on disclosure standards, accountability, and audit committee } \\
\text { independence became effective nationwide. }\end{array}$ \\
\hline Chile & $\begin{array}{l}\text { Major reform, } \\
\text { first reform }\end{array}$ & 2001 & Corporate Governance Law (Ley de OPAS) became effective in 2001. \\
\hline China & $\begin{array}{l}\text { Major reform, } \\
\text { first reform }\end{array}$ & 2001 & $\begin{array}{l}\text { The Chinese Securities Regulatory Commission and the State Economic and } \\
\text { Trade Commission imposed a new Code of Corporate Governance for listed } \\
\text { companies. }\end{array}$ \\
\hline Colombia & $\begin{array}{l}\text { Major reform, } \\
\text { first reform }\end{array}$ & 2001 & Resolution 275 of Supervalores became effective. \\
\hline $\begin{array}{l}\text { Czech } \\
\text { Republic }\end{array}$ & $\begin{array}{l}\text { Major reform, } \\
\text { first reform }\end{array}$ & 2001 & Amendments to the Commercial Code became effective. \\
\hline Denmark & $\begin{array}{l}\text { Major reform, } \\
\text { first reform }\end{array}$ & 2001 & $\begin{array}{l}\text { Recommendations for Good Corporate Governance in Denmark by the Norby } \\
\text { Committee became effective. }\end{array}$ \\
\hline Egypt & $\begin{array}{l}\text { Major reform, } \\
\text { first reform }\end{array}$ & 2002 & $\begin{array}{l}\text { New listing rules by the Cairo \& Alexandria Stock Exchange (CASE) went into } \\
\text { effect. The rules aim to increase disclosure and corporate governance } \\
\text { requirements for listed firms. }\end{array}$ \\
\hline \multirow[t]{2}{*}{ Finland } & Major reform & 2004 & $\begin{array}{l}\text { The Corporate Governance Recommendations for Listed Companies entered } \\
\text { into force on a comply-or-explain basis. }\end{array}$ \\
\hline & First reform & 2003 & $\begin{array}{l}\text { The Corporate Governance Recommendations for Listed Companies became } \\
\text { effective. }\end{array}$ \\
\hline \multirow[t]{2}{*}{ France } & Major reform & 2003 & The Financial Security Law became effective. \\
\hline & First reform & 2001 & Law on New Economic Regulations became effective. \\
\hline Germany & $\begin{array}{l}\text { Major reform, } \\
\text { first reform }\end{array}$ & 2002 & $\begin{array}{l}\text { The initial version of the German Code of Corporate Governance became } \\
\text { effective. The Transparency and Disclosure Law requires compliance with the } \\
\text { code on a comply-or-explain basis. }\end{array}$ \\
\hline \multirow[t]{2}{*}{ Greece } & Major reform & 2002 & Law 3016/2002 became effective. \\
\hline & First reform & 1999 & $\begin{array}{l}\text { Mertzanis Report: Principles of Corporate Governance in Greece: } \\
\text { Recommendations for its Competitive Transformation became effective. }\end{array}$ \\
\hline
\end{tabular}




\section{APPENDIX A, CONTINUED}

\begin{tabular}{|c|c|c|c|}
\hline Country & Reform & Year & Description \\
\hline Hong Kong & $\begin{array}{l}\text { Major reform, } \\
\text { first reform }\end{array}$ & 2005 & $\begin{array}{l}\text { The Exposure Draft Code on Corporate Governance Practices became } \\
\text { effective. }\end{array}$ \\
\hline Hungary & $\begin{array}{l}\text { Major reform, } \\
\text { first reform }\end{array}$ & 2003 & $\begin{array}{l}\text { Budapest Stock Exchange instituted the Corporate Governance Guidelines } \\
\text { Code for listed companies. }\end{array}$ \\
\hline \multirow[t]{2}{*}{ India } & Major reform & 2002 & Clause 49 became effective. \\
\hline & First reform & 1998 & The Report on Desirable Corporate Governance in India became effective. \\
\hline \multirow[t]{2}{*}{ Indonesia } & Major reform & 2007 & $\begin{array}{l}\text { A new Company Law that introduced explicit duties for board members } \\
\text { became effective }\end{array}$ \\
\hline & First reform & 2000 & Code for Good Corporate Governance became effective. \\
\hline Israel & $\begin{array}{l}\text { Major reform, } \\
\text { first reform }\end{array}$ & 2000 & The Companies Law came into effect. \\
\hline Italy & $\begin{array}{l}\text { Major reform, } \\
\text { first reform }\end{array}$ & 2006 & $\begin{array}{l}\text { Law } 262 \text { (Savings Law) became effective. The Borsa Italiana instituted } \\
\text { the Corporate Governance Code. }\end{array}$ \\
\hline Japan & $\begin{array}{l}\text { Major reform, } \\
\text { first reform }\end{array}$ & 2002 & A major reform of the Commercial Code became effective. \\
\hline Malaysia & $\begin{array}{l}\text { Major reform, } \\
\text { first reform }\end{array}$ & 2001 & The Malaysian Code on Corporate Governance became effective. \\
\hline \multirow[t]{2}{*}{ Mexico } & Major reform & 2001 & Major amendments to the Securities Market Law became effective. \\
\hline & First reform & 1999 & $\begin{array}{l}\text { The Corporate Governance Code became effective, and CNBV (National } \\
\text { Banking and Securities Commission) issued a circular requiring that } \\
\text { companies file comply-or-explain reports on compliance with the Código } \\
\text { de Mejores Practicas Corporativas (CMP). }\end{array}$ \\
\hline \multirow[t]{2}{*}{ Netherlands } & Major reform & 2004 & The Dutch Corporate Governance Code became effective. \\
\hline & First reform & 1997 & $\begin{array}{l}\text { The Corporate Governance in the Netherlands Report: The Forty } \\
\text { Recommendations (Peters Report) went into effect. }\end{array}$ \\
\hline Norway & $\begin{array}{l}\text { Major reform, } \\
\text { first reform }\end{array}$ & 2005 & The Code of Practice for Corporate Governance became effective. \\
\hline Pakistan & $\begin{array}{l}\text { Major reform, } \\
\text { first reform }\end{array}$ & 2002 & $\begin{array}{l}\text { The Code of Corporate Governance, published by the Securities and } \\
\text { Exchange Commission of Pakistan (SECP), became effective. }\end{array}$ \\
\hline \multirow[t]{2}{*}{ Peru } & Major reform & 2005 & $\begin{array}{l}\text { Code of Good Corporate Governance became effective on a comply-or- } \\
\text { explain basis for listed companies. }\end{array}$ \\
\hline & First reform & 2002 & $\begin{array}{l}\text { The code established by a committee set up by CONASEV (National } \\
\text { Supervisory Commission for Companies and Securities) became effective. }\end{array}$ \\
\hline Philippines & $\begin{array}{l}\text { Major reform, } \\
\text { first Reform }\end{array}$ & 2002 & The Securities and Exchange Commission made effective Circular \#2. \\
\hline Poland & $\begin{array}{l}\text { Major reform, } \\
\text { first reform }\end{array}$ & 2002 & $\begin{array}{l}\text { The Warsaw Stock Exchange made effective The Best Practices in Public } \\
\text { Companies Code for listed companies on a comply-or-explain basis. }\end{array}$ \\
\hline \multirow[t]{2}{*}{ Portugal } & Major reform & 2001 & $\begin{array}{l}\text { The Securities and Exchange Commission's Recommendations on the } \\
\text { Governance of Listed Companies went into effect. }\end{array}$ \\
\hline & First reform & 1999 & The Securities Market Commission Recommendations became effective. \\
\hline Singapore & $\begin{array}{l}\text { Major reform, } \\
\text { first reform }\end{array}$ & 2003 & The Code of Corporate Governance became effective. \\
\hline
\end{tabular}




\section{APPENDIX A, CONTINUED}

\begin{tabular}{|c|c|c|c|}
\hline Country & Reform & Year & Description \\
\hline South Korea & $\begin{array}{l}\text { Major reform, } \\
\text { first reform }\end{array}$ & 1999 & $\begin{array}{l}\text { A number of laws and regulations dealing with corporate governance } \\
\text { became effective. }\end{array}$ \\
\hline \multirow[t]{2}{*}{ Spain } & Major reform & 2006 & The Corporate Governance Unified Code became effective. \\
\hline & First reform & 1998 & The governance code The Olivencia Report went into effect. \\
\hline \multirow[t]{2}{*}{ Sweden } & Major reform & 2006 & $\begin{array}{l}\text { The Code on Corporate Governance for listed companies became effective } \\
\text { on a comply-or-explain basis. }\end{array}$ \\
\hline & First reform & 2005 & A revision of the Companies Act of 1975 became effective. \\
\hline Switzerland & $\begin{array}{l}\text { Major reform, } \\
\text { first reform }\end{array}$ & 2002 & $\begin{array}{l}\text { The Directive on Information Relating to Corporate Governance issued by } \\
\text { the Swiss Exchange and the Swiss Code of Best Practice for Corporate } \\
\text { Governance became effective. }\end{array}$ \\
\hline Thailand & $\begin{array}{l}\text { Major reform, } \\
\text { first reform }\end{array}$ & 2002 & $\begin{array}{l}\text { The Stock Exchange of Thailand (SET) made effective the Principles of } \\
\text { Good Corporate Governance. }\end{array}$ \\
\hline \multirow[t]{2}{*}{ Turkey } & Major reform & 2002 & $\begin{array}{l}\text { The Code of Best Practice was made effective by TÜSÝIAD (Turkish } \\
\text { Industrialists' and Businessmen's Association). }\end{array}$ \\
\hline & First reform & 1999 & Amendments to the Capital Markets Law were made effective. \\
\hline U.K. & Major reform & 1998 & $\begin{array}{l}\text { The Combined Code, which merged the Cadbury Report and the Greenbury } \\
\text { Report recommendations, was formed and became effective on a comply- } \\
\text { or-explain basis. }\end{array}$ \\
\hline & First reform & 1992 & The Cadbury Report became effective. \\
\hline U.S. & $\begin{array}{l}\text { Major reform, } \\
\text { first reform }\end{array}$ & 2003 & $\begin{array}{l}\text { The major provisions of the } 2002 \text { Sarbanes-Oxley Act (SOX) became } \\
\text { effective. }\end{array}$ \\
\hline
\end{tabular}




\section{APPENDIX B \\ Variable Definitions}

\section{Variables of interest}

Tobin's $q=$ Total assets less book value of equity plus market value of equity divided by book value of total assets.

Post $=$ Indicator variable equals one starting the year $(t=1)$ in which the board reform becomes effective in the country and zero otherwise.

\section{Control variables}

Size $=$ Log of total assets (in millions of dollars).

$P P E=$ Property, plant, and equipment as a percent of total sales.

$A g e=\log$ of firm age. Firm age is the number of years since the firm was incorporated. When the date of incorporation is unavailable, we compute firm age as the number of years since the firm first appeared on the DataStream and WorldScope database.

$R \& D=$ Two-year average of the ratio of research and development expenses to sales.

Foreign Sales $=$ Two-year average of the ratio of foreign sales to sales.

Capex $=$ Capital expenditures as a percent of total assets.

Cash $=$ Cash as a percent of total assets.

Leverage $=$ Total debt, including all short- and long-term debt, as a percent of total assets.

Closely Held $=$ Percentage of closely held shares.

$A D R=$ Indicator that equals one if the firm is cross-listed in the U.S. market and zero otherwise.

$\log G D P=\log$ of real gross domestic product per capita (constant US dollars).

$F D I=$ Foreign direct investment, net inflows (percent of GDP).

Industry $q=$ The median Tobin's $q$ in year $t$ for firms in the same industry, based on the Fama and French 17 industries.

\section{Country-level conditional variables}

Rule of Law $=$ The rule of law index from Kaufmann et al. (2009). It captures perceptions of the extent to which agents have confidence in and abide by the rules of society and, in particular, the quality of contract enforcement, property rights, the police, and the courts, as well as the likelihood of crime and violence.

Disclosure = An index of disclosure requirements from La Porta et al. (2006), which equals the arithmetic mean of prospect, compensation, shareholders, inside ownership, contracts irregularity, and transactions.

Code Law = Indicator that equals one for countries with code law origin of their commercial laws and zero for countries with common law origin.

\section{Firm-level conditional variables}

Governance $=$ The firm-level governance index from Aggarwal et al. (2011), which is based on 41 governance attributes covering four broad areas: board, audit, antitakeover provisions, and compensation and ownership. The index is available from 2003 to 2008. We use the average across all years for each firm.

Coverage $=$ The number of sell-side analysts issuing one-year-ahead forecasts.

Forecast Dispersion $=$ The standard deviation of current fiscal year earnings forecasts scaled by the stock price as of prior year-end. 


\section{APPENDIX B, CONTINUED}

\section{Other variables}

$|\mathrm{DACC}|=$ Absolute value of discretionary accruals, measured as the residuals of the modified Jones (1991) model of Dechow et al. (1996).

$I N V=$ Capital expenditures scaled by lagged total assets.

Asset growth $=$ Log of (total assets $t /$ total assets $\left._{t-1}\right)$.

Cash flow $=$ Net income before extraordinary items minus accruals, where accruals $=$ change in current assets - change in cash - change in current liabilities + short-term debt - change in income taxes payable - depreciation, scaled by lagged total assets.

$R O A=$ Net income divided by total assets.

$R O E=$ Net income divided by total equity.

Market-to-Book $=$ Market value of equity divided by book value of equity. 


\section{APPENDIX C \\ Procedure to Develop Propensity-score-matched (PSM) U.K. Benchmark Firms}

The propensity-score-matching approach involves pairing treatment and control firms based on similar observable characteristics (Dehejia and Wahba 2002). We implement this procedure by first estimating a logit regression to model the probability of being a sample treatment firm. Next, we estimate the propensity score for each firm using the predicted probabilities from the logit model. We then match each treatment firm to the control firms by using the nearest neighbor matching technique (with replacement). The estimation result for our logit regression is as follows:

\begin{tabular}{lc}
\hline Variable & Dep. var. $=$ treatment firms \\
\hline Size & $0.342^{* * *}$ \\
Age & $(5.00)$ \\
& $-0.267^{* * *}$ \\
Leverage & $(-4.92)$ \\
& $1.047^{* * *}$ \\
Cash & $(3.88)$ \\
& -0.052 \\
PPE & $(-0.11)$ \\
& 0.022 \\
Foreign Sales & $(0.74)$ \\
& $-1.344^{* * *}$ \\
R\&D & $(-3.36)$ \\
& 0.316 \\
Capex & $(0.96)$ \\
& 0.145 \\
Closely Held & $(0.45)$ \\
& $1.202^{* * *}$ \\
ADR & $(2.60)$ \\
Year fixed effects & $-0.705^{* *}$ \\
Industry fixed effects & $(-2.22)$ \\
Observations & Yes \\
Pseudo R-squared & Yes \\
\end{tabular}

